\title{
Younger Dryas and Holocene environmental change at the Atlantic fringe of Europe derived from lake-sediment stable-isotope records from western Ireland
}

\author{
JONATHAN A. HOLMES, MARKUS LEUENBERGER, KAREN MOLLOY AND MICHAEL \\ O'CONNELL
}

Holmes, J. A., Leuenberger, M., Molloy, K. \& O’Connell, M.: Younger Dryas and Holocene environmental change at the Atlantic fringe of Europe derived from lake-sediment stableisotope records from western Ireland

Western Ireland lies at the Atlantic fringe of Europe and is thus well positioned to record changes in climate linked to North Atlantic circulation. Lake-sediment oxygen and carbon isotopes are sensitive to changes in the atmosphere, the lake catchment and the lake itself, and thus are valuable proxies for long-term environmental change. Here we present Younger Dryas and Holocene stable-isotope records from endogenic and biogenic carbonates from An Loch Mór, a karstic lake on Inis Oírr, Aran Islands, western Ireland. The bulk carbonate and ostracod-derived stable-isotope records are a complex response to regional climatic and local factors. Low oxygen-isotope and high carbon-isotope values in the Younger Dryas most likely reflect low air temperatures and dominance of bedrockderived carbon from the poorly vegetated catchment, but input of detrital carbonate cannot be ruled out. Holocene variations in oxygen-isotope values are likely a response mainly to changes in the isotopic composition of rainfall, evaporative enrichment of lake water and, during the past millennium, incursion of sea-water as a result of regional sea-level rise. A reduction in carbon-isotope values at the Younger Dryas/Early Holocene transition reflects increased input of soil-derived carbon to the lake, modified by changes in aquatic 
productivity. During the past millennium a shift to less negative values is attributed mainly to increasing saline influence. Broad similarities with stable-isotope records from other sites in western Ireland suggest regional climatic controls dominated by North Atlantic atmospheric circulation patterns, although abrupt events, that were possibly unique to An Loch Mór, point to local factors also being important.

Jonathan A. Holmes (j.holmes@ucl.ac.uk), Environmental Change Research Centre, Department of Geography, University College, London, WC1E 6BT, UK; Markus Leuenberger), Climate and Environmental Physics, Physics Institute, University of Bern, 3012 Bern, Switzerland, and Oeschger Centre for Climate Change Research, University of Bern, 3012 Bern, Switzerland; Karen Molloy and Michael O’Connell, Palaeoenvironmental Research Unit, School of Geography, Archaeology and Irish Studies, National University of Ireland Galway, Galway, H91 TK33, Ireland. 
Oxygen- and carbon-isotope values of lake-sediment carbonates are valuable indicators of past climate and environment. Oxygen isotopes reflect water temperature and waterisotope composition during carbonate precipitation: the latter, in turn, is determined by the isotopic composition of precipitation and hydrological processes taking place within the lake (e.g. evaporative enrichment) and its catchment (e.g. surface runoff and groundwater input) (Leng \& Marshall 2004). Carbon isotopes provide information about carbon cycling and sources within the lake (especially the balance of aquatic photosynthesis to decay or organic matter) and its catchment (related to inwash of carbon derived from soils and bedrock) (McKenzie 1985; Leng et al. 2006). Carbon-isotope composition of both biogenic and endogenic carbonate is little affected by temperature, at least directly, but rather depends on the carbon-isotope composition of dissolved inorganic carbon (DIC) (Leng \& Marshall 2004). For biogenic carbonate, species-specific offsets from oxygen-isotope equilibrium may also be important; for bulk carbonates, the addition of detrital carbonate to the sediment may influence the isotope composition and offsets from oxygen-isotope equilibrium may be important, although these are often hard to quantify (Leng \& Marshall 2004).

Given the important role played by North Atlantic Ocean circulation in mediating climate change during the Lateglacial and Holocene in western Europe and the proximity of Ireland to the North Atlantic, Irish lake sediments can be expected to provide valuable climate archives. Such archives provide a wealth of proxy evidence for long-term changes in climate, limnology, vegetation and catchment stability; in coastal locations, they may also provide evidence for sea-level change.

The investigations described in this paper formed part of the EU-funded TIMECHS (Timing and Mechanisms of Holocene Climate Change in NW Europe) project (TIMECHS 
2001), a multidisciplinary investigation of a 14.3-m-long Lateglacial and Holocene sediment sequence recovered from the deepest part of An Loch Mór in mid-August 1996 (Molloy \& O'Connell 2007). Publications are available relating to pollen (Molloy \& O'Connell 2004, 2014; O'Connell \& Molloy 2019), tephrochronology (Chambers et al. 2004), inorganic geochemistry (Schettler \& Romer 2006; Schettler et al. 2006), and ostracods and other palaeoenvironmental indicators (Holmes et al. 2007). These papers document substantial and, at times, rapid changes in local and regional environments over the last $\sim 13000$ years. The Younger Dryas was characterised by solifluction and absence of tall woody vegetation on Inis Oírr (Molloy \& O'Connell 2014). In the Early Holocene, rapid spread of thermophilous species led to establishment of a complete hazel (Corylus avellana) cover by 10000 cal. a BP and shortly afterwards canopy-forming trees including pine (Pinus sylvestris), oak (Quercus petraea and/or Q. robur) and elm (probably Ulmus glabra) (Molloy \& O'Connell 2014). During this time, lake level was considerably lower than at present (Holmes et al. 2007). Sea levels were also low (Edwards \& Craven 2017; O'Connell \& Molloy 2017; Shennan et al. 2018), but ostracod and other evidence point to slightly brackish lake conditions (Holmes et al. 2007). In the Early Holocene, woodland perturbations, ascribed to regional climatic deteriorations at 9200 and 8200 cal. a BP, are recorded. In the Middle Holocene, a sequence of changes is recorded that include an Elm Decline, Landnam, i.e. woodland clearance ascribable to Neolithic activity, and a rapid expansion of yew (Taxus baccata) followed by retraction that coincided with the start of major clearances in the late Neolithic/early Bronze Age, i.e. c. 4860 cal. a BP (Molloy \& O'Connell 2014). Schettler et al. (2006) suggest, on the basis of geochemical evidence, that marine influence started at c. 5000 cal. a BP. On the basis of ostracod, lithological and regional sea-level rise, appreciable marine incursion probably started much later (at $c$. 1000 cal. a BP) and quickly led to distinctly brackish conditions being established, similar to those pertaining at present (Holmes et al. 2007). 
Here, we present oxygen- and carbon-isotope data derived from biogenic and putative endogenic carbon from Younger Dryas and Holocene sediments of An Loch Mór, as well as water-isotope and other chemical and physical data from the modern lake. This information is used, in conjunction with published data, to gain new insights into environmental change, including climate history, from shortly after 12000 cal. a BP to recent times.

\section{Study area, material and methods}

\section{Study area}

An Loch Mór $\left(53^{\circ} 3.4^{\prime} \mathrm{N} ; 9^{\circ} 30.5^{\prime} \mathrm{W}\right)$, the largest and deepest lake on the Aran Islands, is the only permanent waterbody on the island of Inis Oírr, the smallest and most easterly of the three main islands that constitute a small archipeligo at the mouth of Galway Bay, western Ireland (Figs 1, 2). The lake occupies a deep basin in lower Carboniferous karstified limestone bedrock. The lake surface is close to modern sea level. The lake catchment of $\sim 36.5$ ha includes exposed rock surfaces, and small fields with thin plaggen soils (anthropogenic mixtures of sand and seaweed) that are bounded by high stone walls (Fig. 2). The fields are nowadays under pasture but, until relatively recently, were often cultivated and carried mainly potatoes, rye and oats (O'Connell \& Molloy 2019). Though ice-covered in the last glaciation (Peters et al. 2015), glacial deposits consist largely of limestone and granite erratics (Feehan 1994). Inis Oírr has a mild oceanic climate with mean July and January temperatures of $\sim 15.5$ and $6.5^{\circ} \mathrm{C}$, respectively, and mean annual precipitation between 1200 and 1400 mm (Walsh 2012). An Loch Mór is currently slightly brackish ( $\sim 5$ practical salinity units (PSU) in summer) as a result of diurnal influx of sea- 
water through the narrow, jointed, limestone-bedrock barrier. Sea-spray is also a likely contributor of salt, given the lake's proximity to the Atlantic Ocean (cf. Drinan et al. 2013).

\section{Lake-water investigations}

In October 1997, prior to commencement of the TIMECHS project, lake-water temperature had been profiled close to the deepest part of the lake by pupils of the local secondary school. In 1998 (21 August) and 1999 (1 June), the water column at close to the main coring location (Fig. 2), was profiled at $\sim 1 \mathrm{~m}$ intervals for temperature, salinity, dissolved oxygen and conductivity using a YSI, model 33, S-C-T meter. During the latter investigations, water samples (volume $\sim 200 \mathrm{~cm}^{3}$ ) were collected to investigate the geochemical characteristics of the water column. Oxygen-isotope determinations were undertaken at the Climate and Environmental Physics (CEP) laboratory of the University of Bern using a Finnigan MAT 250 mass spectrometer and the results were expressed in delta units relative to the VSMOW standard with an uncertainty of $\pm 0.1 \%$ for $\delta^{18} \mathrm{O}$.

\section{Bulk-carbonate and ostracod-shell stable-isotope determinations}

The sediments from core MOR1, which was used for most of the investigations, are organic-rich over considerable intervals. This reduced the possibility of locating suitable material for bulk-carbonate analyses over the entire length of the sequence. It was, however, possible to obtain samples for stable-isotope analyses from 130 levels. The samples were 1 or $0.5 \mathrm{~cm}$ thickness, the latter thickness and continuous sampling being used to investigate the abrupt events at 8.2 and 9.2 ka BP. In these samples, carbonate content varied between 3 and $75 \%$. A sample of the catchment bedrock (Carboniferous limestone) was also analysed. Analysis of oxygen and carbon isotopes was carried out 
using a Thermo Fisher XP mass spectrometer at CEP, following methods described in Eicher (1979).

Ostracod shells were extracted from the dried, $>125 \mu \mathrm{m}$ fraction of sediment that was sampled in $1 \mathrm{~cm}$ thick slices. Samples, typically of 2-8 monospecific shells, weighing between 20-100 $\mathrm{\mu g}$ in total, were analysed for oxygen and carbonate isotopes using a Thermo Fisher XP mass spectrometer at CEP. Because a single species was not found throughout the core, analyses were undertaken on shells of three species, namely Sarscypridopsis aculeata, Cyprideis torosa and Cyclocypris ovum, to provide maximum temporal coverage. Oxygen- and carbon-isotope ratios for bedrock, bulk sediments and ostracods are expressed in delta units relative to the VPDB standard with typical uncertainties of $\pm 0.3 \%$ and $\pm 0.2 \%$ for $\delta^{18} \mathrm{O}$ and $\delta^{13} \mathrm{C}$, respectively.

\section{Results and interpretation}

\section{Present-day lake water}

The oxygen-isotope composition of lake water $\left(\delta^{18} \mathrm{O}_{\mathrm{L}}\right)$ from An Loch Mór in summer 19981999 was $-2.81 \pm 0.04 \%$ in surface waters (above the thermocline at about 5 to $7 \mathrm{~m}$ depth) and around $-3.22 \pm 0.12 \%$ in deeper waters (Fig. 3). $\delta^{18} \mathrm{O}_{\mathrm{L}}$ in the lake is likely to be controlled by the oxygen-isotope composition of rain water $\left(\delta^{18} \mathrm{O}_{p}\right)$, groundwater $\left(\delta^{18} \mathrm{O}_{\mathrm{gw}}\right)$ and sea water $\left(\delta^{18} \mathrm{O}_{\mathrm{sw}}\right)$ and the relative contributions from these components, together with modification by evaporative enrichment.

There are no records of the isotopic composition of rainwater from Inis Oírr. However, the long (c. three decades) GNIP record of $\delta^{18} \mathrm{O}_{\mathrm{p}}$ from Valentia $(\sim 140 \mathrm{~km} \mathrm{SSW}$ 
of Inis Oírr, but at a similar altitude and distance from the coast) provides a useful indication. Here, the long-term weighted annual average $\delta^{18} \mathrm{O}_{p}$ value is $-5.4 \%$ (Rozanski et al. 1993). The much shorter (June 2004-December 2005) time-series from Carran, in the central southern Burren, Co. Clare, to the east of An Loch Mór but on the mainland, at $\sim 21$ $\mathrm{km}$ from the coast and $130 \mathrm{~m}$ a.s.I., has a mean $\delta^{18} \mathrm{O}_{\mathrm{p}}$ of $\sim-6 \%$ (Holmes et al. 2016), consistent with its inland and upland location (Diefendorf \& Patterson 2005). The best approximation for $\delta^{18} \mathrm{O}_{\text {sw }}$ is $0.7 \%$ (Bigg \& Rohling 2000). We have no data for $\delta^{18} \mathrm{O}_{\mathrm{gw}}$ on Inis Oírr, but we assume that it approximates the long-term weighted annual average $\delta^{18} \mathrm{O}_{p}$ value. The data in Einsiedl (2012), which relate to karstic sites in the nearby north Burren (Fig. 1), support the suppositions made above.

There is no detailed water balance for An Loch Mór. The lake-water residence time is probably somewhat over a year, based on a lake area of 6.54 ha, lake volume of $\sim 400000 \mathrm{~m}^{3}$, a catchment area of 36.5 ha and annual precipitation of $1200 \mathrm{~mm}$, of which around half that falls on the catchment reaches the lake. Diurnal input of seawater, which has not been quantified, further complicates the picture and means that the suggested residence time is an under-estimate. However, the salinity of the present-day lake can be used to used to estimate of the relative contributions of meteoric water and sea-water sources.. On the basis of an average salinity of $\sim 5$ PSU during the late 1990 s, we estimate $86 \%$ and $14 \%$ contributions from these sources, , respectively. This is expected to give a $\delta^{18} \mathrm{O}_{\mathrm{L}}$ value of $-4.5 \%$ o, i.e. $(-5.4 \times 0.86)+(0.7 \times 0.14)$. This is rather more negative than measured values, both at the lake surface and in the deeper water, suggesting that other processes may have been important. There is also evidence, from the higher $\delta^{18} \mathrm{O}_{\mathrm{L}}$ values in water above the thermocline in summer, that the lake water undergoes evaporative enrichment (Fig. 3). The lake most likely does not freeze regularly in the mild maritime climate of western Ireland, but overturns in autumn-winter (Holmes et al. 2007), as 
suggested by the October temperature profile (Fig. 3), so that heavy-isotope-enriched surface waters become mixed with deeper waters leading to a modification of the entire water column. However, the short residence time means that evaporative enrichment alone may not fully explain the difference, but nevertheless it is probably the main factor involved.

Using modern-water isotope composition of the lake (-2.6 to $-2.9 \%$ ) and measured summer temperatures $\left(18^{\circ} \mathrm{C}\right)$, we can predict the isotopic composition of calcite formed in oxygen-isotope equilibrium with lake water to be in the range -3.5 and $-3.8 \%$ in the epilimnion, based on the equation of Kim \& O'Neil (1997) and assuming that authigenic calcite is produced in the spring-summer as a result of the photosynthetic drawdown of $\mathrm{CO}_{2}$ and its impact on calcite saturation, as has been suggested in previous studies in mid-latitude hardwater lakes (e.g. Marshall et al. 2007). The corresponding $\delta^{18} \mathrm{O}_{\mathrm{c}}$ value in the hypolimnion $\left(\delta^{18} \mathrm{O}_{\mathrm{L}}=-3.3 \%\right.$ and $\left.\mathrm{T}=8.6{ }^{\circ} \mathrm{C}\right)$ is $\sim-2.1 \%$. We have no modern or coretop bulk-carbonate isotope analyses $\left(\delta^{18} \mathrm{O}_{\mathrm{c}}\right)$ with which to compare these predictions. However, a near core-top ostracod sample (from $44 \mathrm{~cm}$ ) of multiple shells of $S$. aculeata yielded a $\delta^{18} \mathrm{O}$ value of $-2.94 \%$. This species matures in summer (Meisch 2000), so it seems reasonable to accept that the measured temperature and $\delta^{18} \mathrm{O}_{\mathrm{L}}$ values quoted above may be reliably used in the calculations. The measured $\delta^{18} \mathrm{O}$ value is in reasonable agreement with the predicted values given uncertainties in the temperature and oxygenisotope composition of lake water at the precise time of ostracod shell formation, and lack of knowledge of offsets from oxygen-isotope equilibrium in this species (cf. Holmes \& Chivas 2002). 
The carbon-isotope composition of lake DIC depends on the relative contribution and isotopic composition of different carbon sources (Kelts \& Talbot 1990). DIC in the groundwater source typically reflects a 50:50 mixture of soil-derived $\mathrm{CO}_{2}\left(\delta^{13} \mathrm{C}=-30 \%\right.$ o to $20 \%$ in C3 vegetation regions (Smith \& Epstein 1971)) and limestone bedrock $\left(\delta^{13} \mathrm{C}\right.$ for the local Carboniferous limestone bedrock $=+0.12 \%$ ), which is expected to give a $\delta^{13} C_{D I C}$ value of $\sim-15 \%$ o to $-10 \%$. The dissolution/precipitation of calcite also potentially influences the carbon-isotope signature. The degree of saturation with respect to calcite is dependent on $\mathrm{pH}$, which, in turn, determines the proportion of DIC present in carbonate ion $\left(\mathrm{CO}_{3}{ }^{2-}\right)$ form. A higher $\mathrm{pH}$ value leads to an increase in $\left[\mathrm{CO}_{3}^{2-}\right]$, which is expected to lead to a change in the $\delta^{13} \mathrm{C}$ of carbonate because of carbonate-bicarbonate fractionation $(-2.6 \%$ : Zhang et al. 1995; Zeebe \& Wolf-Gladrow 2001). The $\delta^{13} \mathrm{C}$ signature can also be modified within the lake as a result of aquatic photosynthesis and the decay of organic matter. Photosynthesis by aquatic plants preferentially uses ${ }^{12} \mathrm{C}$, leading to an enrichment of ${ }^{13} \mathrm{C}$ within DIC and an increase in $\delta^{13} \mathrm{C}_{\mathrm{DIC}}$, whereas the mineralisation of ${ }^{13} \mathrm{C}$-depleted organic carbon will lower $\delta^{13} \mathrm{C}_{\mathrm{DIC}}$ values. In many lakes, changes in $\delta^{13} \mathrm{C}_{\mathrm{DIC}}$ and hence $\delta^{13} \mathrm{C}$ of sedimentary carbonate are controlled by the balance of aquatic photosynthesis to decay of organic matter, and $\delta^{13} \mathrm{C}$ can therefore be used as a first-order proxy for aquatic productivity (McKenzie 1985). There is also a $1 \%$ enrichment of ${ }^{13} \mathrm{C}$ in calcite compared with bicarbonate (Romanek et al. 1992). For ostracod calcite, there does not appear to be any significant carbon-isotope vital offset (Keatings et al. 2002).

We do not have modern $\delta^{13} C_{D I C}$ values for An Loch Mór. However, $\delta^{13} \mathrm{C}$ values in core-top ostracods provide a useful proxy for $\delta^{13} \mathrm{C}_{\mathrm{DIC}}$ values. The $\delta^{13} \mathrm{C}$ of near core-top specimens of $S$. aculeata is $\sim-1.7 \%$, which equates to a value of $\sim-2.7 \%$ in DIC (assuming DIC is predominantly $\mathrm{HCO}_{3}{ }^{-}$). This value is considerably more ${ }^{13} \mathrm{C}$-enriched than the 
estimated $\delta^{13} \mathrm{C}$ of groundwater DIC (see above), which, in turn, suggests that the composition of lake DIC has been modified by in-lake processes such as aquatic photosynthesis. This is quite possible given the major expansion of Potamogeton pectinatus (fennel pondweed) in the northern shallow part of the lake since the 1950s due to a rise in trophic status, the result of groundwater pollution (Molloy \& O'Connell 2004).

\section{Records from core MOR1}

The chronology for core MOR1, as used in this paper (and all papers since 2012 when the age/depth model was constructed), is based on several lines of evidence including radiocarbon dating, cryptotephra, ${ }^{210} \mathrm{~Pb}$ and correlation of palynological markers with Greenland ice cores (Fig. 4). The Younger Dryas interval consists of typical clay-rich silty sediments whereas the Holocene part consists of gyttja (Fig. 4), with varying proportions of organic carbon and calcium carbonate (Fig. 5). High proportions of calcium carbonate, as are often found in calcareous lakes, are best explained by enhanced aquatic photosynthesis, possibly coupled with greater input of carbonate-bearing freshwater from the limestone catchment (Schettler et al. 2006). Intrusion of seawater, which contains high concentrations of crystal-inhibiting magnesium and phosphorus, as well as decreased temperature (increases $\mathrm{CO}_{2}$ solubility and hence reduces calcium carbonate precipitation) act to reduce the formation of calcium carbonate (Schettler et al. 2006). Variations in the organic carbon content of the sediments are best explained by aquatic productivity coupled with organic matter preservation, which in turn is linked to water-column oxidation (Schettler et al. 2006).

The isotope record from bulk carbonates extends from near the end of the Younger Dryas until $\sim 3800$ cal. a BP. In all, 78 ostracod samples were processed, 65 of which 
yielded sufficient shell of the selected species. The ostracod-isotope record covers selected intervals between the earliest Holocene and recent time, but with large gaps where no ostracods were found in core MOR1 (Fig. 5). Oxygen-isotope and carbonisotope values in the bulk sediment vary between $-6.3 \%$ and $+0.26 \%$, and $-4.7 \%$ and $+1.6 \%$, respectively, and for the local Carboniferous limestone, the corresponding values are $-6.82 \%$ and $+0.12 \%$.

The lowest $\delta^{18} \mathrm{O}_{\mathrm{c}}$ values, $\sim-6.3 \%$, are found in the earliest part of the record corresponding to the upper part of the Younger Dryas stadial. Values increase to -3\% in the Early Holocene with one excursion towards stadial conditions at c. $10800 \mathrm{cal}$. a BP. Following a gap of 700 years in the record coinciding with carbonate-poor sediment, there was a sharp positive excursion of $\sim 4 \%$ at c. 9400 cal. a BP with smaller amplitude ( $2 \%$ o $)$ positive excursions between $\sim 8600$ and 8000 cal. a BP. After this, the $\delta^{18} \mathrm{O}_{c}$ values averaged $\sim-4.5 \%$, but with a slight trend towards more negative values. Several minor oscillations are mostly constrained by single data points. The major positive excursions correlate with intervals of decreased $\mathrm{CaCO}_{3}$ within the sediments, although this relationship does not hold for the entire record (Fig. 6).

The highest $\delta^{13} \mathrm{C}_{\mathrm{c}}$ values, of up to $+1.6 \%$, are found near the base of the record in the Younger Dryas. Values decline sharply to <-3\% in the Early Holocene. Negative excursions occur at 10500 cal. a BP and also in the interval c. 9400-9250 cal. a BP, broadly coincident with marked positive excursion in $\delta^{18} \mathrm{O}_{c}$, but, unlike $\delta^{18} \mathrm{O}_{c}, \delta^{13} \mathrm{C}_{c}$ values vary little between 8600 and 8000 cal. a BP. There is a steady increase in $\delta^{13} C_{c}$ values in the interval $9000-5200$ cal. a BP of $\sim 3.5 \%$, followed by a sharp negative excursion with an amplitude of $3 \%$ thereafter. There is a weak negative correlation between $\delta^{13} \mathrm{C}_{c}$ values and 
$\mathrm{CaCO}_{3}$ content between 11000 and 9000 cal. a BP, and a weak positive relationship in the interval 9000-5000 cal. a BP (Fig. 6).

The ostracod-based isotope record is patchier than that based on bulk carbonates, but it is only the former that provides data relating to the most recent past (last c. 1000 years). Stable-isotope analyses were undertaken on shells of the three ostracod species as follows: Cyprideis torosa from the lowermost part of the sequence and from sediments relating to the past millennium, Cyclocypris ovum from the interval $9700-7400$ cal. a BP, and Sarscypridopsis aculeata from the core top and one sample from near the top (250 cal. a BP, c. AD 1700).

The mean $\delta^{18} \mathrm{O}$ value $\left(\delta^{18} \mathrm{O}_{\text {ost }}\right)$ for $C$. torosa is $-3.06 \pm 0.75 \%$ o $(n=30)($ Fig. 5$)$. The three values from the earliest Holocene are more negative $(-3.49 \pm 0.22 \%$ ) than the overall mean. Following a long gap in the $C$. torosa record, values in the interval $6000-3000$ cal. a $\mathrm{BP}$ - the temporal resolution is low here - are less negative $(-2.67 \pm 0.76 \%$ ). Following a substantial interval without records, values for the past 1000 years are slightly more negative but highly variable $(-3.11 \pm 0.77 \%$ o, $n=21)$. The most negative individual values $(<-$ $4 \%$ ) relate to the Late Holocene. $\delta^{18} \mathrm{O}_{\text {ost }}$ data derived from C. ovum cover the interval $\sim 10$ 000-7000 cal. a BP and, on average, are the least negative and variable of the entire sequence $(-2.83 \pm 0.42 \%$ o, $n=32)$. The values derived from $S$. aculeata fall within the range of values for $C$. torosa that relate to the most recent few centuries.

The mean $\delta^{13} \mathrm{C}$ value $\left(\delta^{13} \mathrm{C}_{\text {ost }}\right)$ for $C$. torosa is $-4.34 \pm 2.16 \%$. The lowest values are found in the Early Holocene $(-8.12 \pm 1.66 \%$ o $n=3)$. Values are variable but less negative between 6000 and 3000 cal. a BP $(-6.22 \pm 2.0 \%, n=6)$ and less negative still in the most 
recent 1000 years $(-3.26 \pm 1.10 \%, n=21)$, during which time $\delta^{13} \mathrm{C}$ values increased by $c$. $1.8 \% \mathrm{ka}^{-1}$. The most negative $\delta^{13} \mathrm{C}_{\mathrm{ost}}$ value, $-9.34 \%$, was recorded in the Early Holocene whereas the most positive value, $-1.8 \%$, relates to a sample dating to $c$. AD $1750(\sim 200$ cal. a BP). $\delta^{13} C_{\text {ost }}$ values for $C$. ovum in the interval $9700-7400$ cal. a BP are $-3.7 \pm 1.47 \%$. The values for S. aculeata (mainly of recent age) fit the same broad trend as shown by those for $C$. torosa, though only $S$. aculeata returned a positive value for $\delta^{13} C_{o s t}(+0.66 \%$; core-top sample).

Values for $\delta^{13} \mathrm{C}$ and $\delta^{18} \mathrm{O}$ in the bulk-carbonate samples show a non-linear negative correlation (Fig. 7) but this relationship is mainly constrained by Younger Dryas samples, which are characterised by low $\delta^{18} \mathrm{O}$ and high $\delta^{13} \mathrm{C}$ values, and by the Early Holocene oxygen-isotope excursion, where the reverse is the case. The ostracod data show no clear relationship between $\delta^{13} \mathrm{C}$ and $\delta^{18} \mathrm{O}$ (Fig. 7).

Where bulk- and ostracod-isotope values are available for identical or stratigraphically close $( \pm 1 \mathrm{~cm})$ levels, $\delta^{18} \mathrm{O}_{\text {ost }}$ values are typically more positive than $\delta^{18} \mathrm{O}_{\mathrm{c}}$ (differences are $1.1 \pm 1.1 \%$ and $0.4 \pm 1.2 \%$ for $C$. torosa and $C$. ovum, respectively, i.e. the differences are variable). For $\delta^{13} \mathrm{C}$ the pattern is more complex. $\delta^{13} \mathrm{C}$ values in $C$. torosa are more negative than in the bulk samples whereas for $C$. ovum there is no clear difference (Fig. 8).

\section{Discussion}

The main potential controls on the oxygen-isotope records, which are described above, are water temperature and water-isotope composition at the time of calcification for 
oxygen; for carbon isotopes, isotopic composition of DIC is the primary control. An additional consideration relating to the interpretation of the bulk-carbonate isotope record is the origin of the carbonate. Of particular importance is whether the carbonate is predominantly autochthonous. If it is, then the records provide a proxy for the temperature (oxygen) and isotope composition of water (oxygen), and DIC (carbon) at the time of calcification. If, on the other hand, there is a significant allochthonous component from the catchment's limestone bedrock, then there is the distinct possibility of detrital carbonate entering the lake, in which case the isotope records are more difficult to interpret. For the Holocene part of the core, however, there is strong evidence that the carbonate is primarily autochthonous for the following reasons: (i) there is broad agreement with the ostracodisotope data, or, where differences occur, they can be readily explained. For example, the more positive $\delta^{18} \mathrm{O}$ values in ostracods (Fig. 8) compared with the bulk carbonate samples are attributable to two factors. Firstly, ostracod shells calcify in the colder hypolimnion of the lake, whereas authigenic carbonate precipitates in spring-summer in the warmer epilimnion. Secondly, there is the well-documented positive oxygen-isotope vital offset in ostracod calcite (Holmes \& Chivas 2002). For $\delta^{13} \mathrm{C}$, the more negative ostracod compared with bulk carbonate values (Fig. 8) can be explained by the fact that ostracod shells calcify close to the sediment-water interface, where $\delta^{13} \mathrm{C}$ of DIC is influenced by ${ }^{13} \mathrm{C}$-depleted carbon from decay of organic matter: in contrast, authigenic carbonate forms in the epilimnion, where aquatic photosynthesis results in ${ }^{13}$ C-enriched DIC (Kelts \& Talbot 1990); (ii) strontium-isotope values for the Early- to Middle-Holocene parts of the core (we have no data for the Lateglacial) are consistent with the carbonate being autochthonous. ${ }^{87} \mathrm{Sr} /{ }^{86} \mathrm{Sr}$ values in ostracod shells, which record the Sr-isotope ratio of $\mathrm{Sr}$ in lake water, varied between $0.708709 \pm 0.000014(2 \mathrm{~s})$ and $0.708897 \pm 0.000014(2 \mathrm{~s})$ and values for weak-acid leaches of carbonates from the same interval $(0.708765 \pm 0.000030$ to $0.708870 \pm 0.000030$ ), fall within this range, whereas values for limestone bedrock in the 
catchment are significantly different (mean 0.707840 $\pm 0.00012, \mathrm{n}=5)$ (Holmes et al. 2007). For the Younger Dryas, ruling out a detrital component to the sediment is more difficult. Ostracods were not recorded in this part of the sequence and we have no Sr-isotope determinations to shed light on the origin of the sediment. Although the changes in $\delta^{18} \mathrm{O}_{\mathrm{c}}$ and $\delta^{13} \mathrm{C}_{\mathrm{c}}$ can be readily explained in environmental terms, and show similarities with other Lateglacial records from western Ireland, similar patterns of change can also be achieved, given the isotopic composition of the catchment limestone, by varying inputs of detrital carbonate.

We now discuss the major temporal changes in the isotope record assuming that the bulk-carbonate isotope values reflect a predominantly authigenic source, except where otherwise indicated.

The earliest part of the record covers the end of the Younger Dryas stadial and the transition to the earliest Holocene. The bulk-carbonate-derived data show a sharp $\sim 3.5 \%$ o rise in $\delta^{18} \mathrm{O}_{c}$ from a minimum of $-6.7 \%$. This minimum Younger Dryas value compares favourably with values at other Younger Dryas sites in western Ireland (Fig. 9), including Lough Gur (-6.8\%:: Ahlberg et al. 1996, 2001), Red Bog (-6\%:: Ahlberg et al. 1996, 2001), Fiddaun Lough (-7.5\%o: van Asch et al. 2012) and Tory Hill ( -6.6\%o: O'Connell et al. 1999). Increases at the transition between Lateglacial and Early Holocene range from $2.6 \%$ at Tory Hill to $4.8 \%$ at Lough Gur. Broadly similar changes are also seen at Lough Inchiquin (Diefendorf et al. 2006), although the chronology for that record is uncertain. The An Loch Mór record includes only the later part of the Younger Dryas, so the minimum $\delta^{18} \mathrm{O}_{\mathrm{c}}$ value for that period may not have been recorded. Ahlberg et al. (1996) suggested that the rise in $\delta^{18} \mathrm{O}_{c}$ values between the Younger Dryas and Early Holocene could be 
explained by a temperature rise of between $\sim 12$ and $14{ }^{\circ} \mathrm{C}$, considering the combined impact of temperature on the isotopic composition of rainfall $\left(+0.58 \%{ }^{\circ} \mathrm{C}^{-1}\right)$ and the calcitewater fractionation $\left(\sim 0.25 \%{ }^{\circ} \mathrm{C}^{-1}\right)$. A similar calculation for the $\delta^{18} \mathrm{O}_{\mathrm{c}}$ values from An Loch Mór suggests a temperature rise of $\sim 10{ }^{\circ} \mathrm{C}$. These estimates are somewhat larger than the Younger Dryas to Early Holocene temperature increase of $\sim 8{ }^{\circ} \mathrm{C}$, inferred from chironomids at Lough Fiddaun, Co. Galway (van Asch et al. 2012) which, in turn, is similar to the temperature increase at Tory Hill suggested by O'Connell et al. (1999), mainly on the basis of pollen and $\delta^{18} \mathrm{O}_{c}$ data from that site. The discrepancy between the palaeoecological and isotopic estimates of temperature increase at the end of the Younger Dryas can be explained by a change in the slope of the relationship between $\delta^{18} \mathrm{O}_{\mathrm{p}}$ and air temperature after the Younger Dryas in response to changing atmospheric circulation in the Early Holocene, as has been postulated by others (e.g. Hammarlund et al. 2002). Similarly changes in local seasonal precipitation distribution and/or source region could alter this relationship (Huber et al. 2006; Kindler et al. 2014). There is also the possibility that sea-water incursion led to increased $\delta^{18} \mathrm{O}_{\mathrm{L}}$ values at An Loch Mór, but this seems unlikely given very low sea levels during this time (Edwards \& Craven 2017), and lack of unequivocal evidence in the lake sediments for elevated salinity (Holmes et al. 2007). Moreover, the changes in $\delta^{18} \mathrm{O}_{c}$ values at An Loch Mór are broadly consistent with those recorded at other lakes in western Ireland referred to above that were not affected by seawater. An input of detrital carbonate from weathered Carboniferous limestone bedrock during the Younger Dryas may have contributed to the low $\delta^{18} \mathrm{O}_{c}$ values at any or all of the sites, as has been postulated by Diefendorf et al. (2006) in respect of the L. Inchiquin data.

The extent to which detrital carbonate has influenced $\delta^{18} \mathrm{O}$ Younger Dryas records from An Loch Mór and other sites requires further investigation (cf. Schettler et al. 2006; also Einsiedl 2012). A change in the evaporative conditions might also influence the 
estimated temperature change, in that part of the shift in $\delta^{18} \mathrm{O}$ that is attributed to temperature increase may be due to greater evaporation in the Holocene compared to that in the Younger Dryas. For example, a $0.7 \%{ }^{18} \mathrm{O}$ enrichment due to increased evaporation could explain the difference between the $8{ }^{\circ} \mathrm{C}$ estimate for temperature change (based on chironomids) and the $10{ }^{\circ} \mathrm{C}$ (based on carbonate isotopes), assuming a slope in the $\delta^{18} \mathrm{O}_{\mathrm{p}}$ - temperature relationship of $0.58-0.25 \%{ }^{\circ} \mathrm{C}^{-1}-$ as used above.

The elevated $\delta^{13} \mathrm{C}_{c}$ values in the final stages of the Younger Dryas at An Loch Mór may be explained by the relatively large proportion of DIC derived from dissolution of limestone bedrock during this interval. Values decrease sharply at the transition to the Early Holocene, a feature best explained by an increased input of catchment-derived soil carbon as soils developed, and the catchment became more densely vegetated as shown by the increase in tree and shrub pollen (Fig. 5; also Fig. S1). This may have contributed to the fall in $\mathrm{CaCO}_{3}$ concentration at this time. A decrease in detrital carbonate input from weathered limestone at the Younger Dryas/Holocene transition could also have contributed to these changes in $\delta^{13} \mathrm{C}$ and $\mathrm{CaCO}_{3}$ values. Similar changes in $\delta^{13} \mathrm{C}_{\mathrm{c}}$ values in the interval identified as Younger Dryas/Holocene transition can be seen in the record from Lough Inchiquin (Diefendorf et al. 2008), and also at Fiddaun Lough where chronological control is tighter (van Asch et al. 2012) (Fig. 9).

The interval 10900 to 9400 cal. a BP in core MOR1 is largely devoid of ostracod shells and carbonate. This is most likely a function of low carbonate production in waters that were under-saturated with respect to calcite, as well as poor ostracod and authigenic carbonate preservation in the organic-rich hypolimnion and at the sediment-water interface. With the exception of the two marked positive $\delta^{18} \mathrm{O}_{c}$ excursions, which are 
discussed in detail below, there is good general agreement between the Holocene $\delta^{18} \mathrm{O}_{\mathrm{c}}$ record from An Loch Mór and those from Lough Corrib (Tibert et al. 2007) and Lough Gur (Ahlberg et al. 1996, 2001) although chronological uncertainties preclude detailed comparison. There is little resemblance between the general patterns in these two records and the $\delta^{18} \mathrm{O}_{c}$ record from Lough Inchiquin (Diefendorf et al. 2008), which displays more negative $\delta^{18} \mathrm{O}_{\mathrm{c}}$ values overall and a contrasting pattern of variability (Fig. 9).

The sharp positive excursions in $\delta^{18} \mathrm{O}_{\mathrm{c}}$ values in the intervals $9400-9140 \mathrm{cal}$. a BP and $8600-8000$ cal. a BP in the MOR1 record are difficult to explain (Fig. 5). The first of these corresponds with a smaller-amplitude positive excursion in $\delta^{18} \mathrm{O}_{\text {ost }}$ values. Both excursions are characterised by large-amplitude variations, which show negative correlation with $\mathrm{CaCO}_{3}$ values (Fig. 6). The first is also marked by a decrease in $\delta^{13} \mathrm{C}$. The response in the pollen differs (Figs 5, S1): in the first excursion there is a small response, with a minor peak in Juniperus, whereas in the second, there is a marked decrease in Corylus. These features in the pollen record are regarded as reflecting shifts in woodland composition, the result of climate downturns associated with the $9.2 \mathrm{ka}$ and $8.2 \mathrm{ka}$ events (cf. Ghilardi \& O'Connell 2013). There is no clear response in the residual (i.e. noncarbonate inorganic fraction) component of the sediment during either excursion (Fig. 5). Two mechanisms could potentially lead to an increase in $\delta^{18} \mathrm{O}_{c}$ values, namely intrusions of sea-water and enhanced evaporative enrichment. We evaluate each of these in turn.

The maximum $\delta^{18} \mathrm{O}_{c}$ value during the first excursion would require calcification from water with a $\delta^{18} \mathrm{O}$ value of $\sim 0 \%$, assuming the calcification temperature was $\sim 14{ }^{\circ} \mathrm{C}$; small $\left( \pm 2{ }^{\circ} \mathrm{C}\right.$, for example) shifts in water temperature would change this value, but not by a significant amount. To elevate $\delta^{18} \mathrm{O}_{\mathrm{L}}$ to $\sim 0 \%$ would require the water balance of the lake to 
have been dominated almost entirely by sea-water, which would in turn require a major marine incursion. However, such a scenario is not consistent with the palaeoecological and other evidence that suggests low salinity during this time (Holmes et al. 2007; Edwards \& Craven 2017), nor with the fact that the positive excursion in $\delta^{18} \mathrm{O}_{\text {ost }}$ is muted.

Evaporative enrichment is an alternative explanation for the positive $\delta^{18} \mathrm{O}_{\mathrm{c}}$ excursions. We know that evaporative enrichment is probably responsible for increasing $\delta^{18} \mathrm{O}$ of present-day lake-surface water (Fig. 3), albeit by less than $1 \%$ o. Moreover, evaporation is expected to have a greater effect in surface compared with subsurface waters, which might explain the difference in amplitude of the positive oxygen-isotope excursion in bulk carbonate compared with that of the ostracods. Positive $\delta^{18} \mathrm{O}$ excursions are evident in the records from Lough Inchiquin (Diefendorf et al. 2006) and possibly Lough Corrib (Tibert et al. 2007), although these are not as pronounced as the excursions, and especially that regarded as reflecting the 9.2 event, at An Loch Mór.

Several further issues remain to be resolved in connection with the positive $\delta^{18} \mathrm{O}$ excursions. Firstly, the degree of evaporation required to elevate the surface water in An Loch Mór to a $\delta^{18} \mathrm{O}$ value close to $0 \%$, which is what the first of the two excursions from An Loch Mór would have entailed were it the result solely of evaporative enrichment, is considerable ( $\sim 40 \%$ water loss, using a simple Rayleigh model). Secondly, evaporative enrichment might be expected to be accompanied by an increase in $\mathrm{CaCO}_{3}$ as surface waters become saturated with respect to calcium carbonate. However, $\mathrm{CaCO}_{3}$ values decrease during these excursions. In short, the causes of the positive $\delta^{18} \mathrm{O}_{c}$ excursions are not easily explained. 
The second of the positive excursions covers the interval associated with the 8200year cooling event seen elsewhere in isotope records from NW Europe (Daley et al. 2011). $A \sim 1 \%$ negative excursion is also present in other $\delta^{18} \mathrm{O}_{c}$ records from lake sediments in western Irish lakes at this time (Holmes et al. 2016). However, such a negative excursion is not evident in the An Loch Mór record, even though the 8200-year event is well expressed in the pollen record (Molloy \& O'Connell 2014; Figs 5, S1): rather, there is an overall rise in $\delta^{18} \mathrm{O}_{c}$ during this interval. We note good correspondence between the shape of the $\delta^{18} \mathrm{O}$ curves in MOR1 and Lough Inchiquin in the interval $8300-8000$ cal. a BP (Fig. 9). Diefendorf et al. (2006) attribute the change in $\delta^{18} \mathrm{O}$ values during the cooling event as a combined response to atmospheric cooling mediated by reduced effective moisture, although chronological uncertainties and the lack of palynological markers make it hard to determine which, if any, of the fluctuations in the $\delta^{18} \mathrm{O}$ curve from $\mathrm{L}$. Inchiquin which has high temporal resolution but poor chronological control, corresponds to the 8200-year cooling. We have no fully satisfactory explanation for the lack of a negative $\delta^{18} \mathrm{O}_{c}$ excursion at An Loch Mór and conclude that other factors apart from the decrease in $\delta^{18} \mathrm{O}_{p}$ in response to the atmospheric cooling that is known to have occurred, were operating at this site during the Early Holocene and that these acted to override the atmospheric signal.

From c. 8000 cal. a BP until the end of the bulk-carbonate isotope record at c. 3800 cal. a BP, $\delta^{18} \mathrm{O}_{\mathrm{c}}$ values remain steady, consistent with a slightly saline (based on the ostracod faunas; Holmes et al. 2007), moderately evaporated lake, but without substantial marine input. Higher $\delta^{13} \mathrm{C}_{c}$ values suggests increased aquatic productivity. The steady rise in $\mathrm{CaCO}_{3}$ values over the same interval supports this conclusion, since increased productivity in the epilimnion would draw down $\mathrm{CO}_{2}$, leading to calcite saturation. 
Over the last 1000 years, the widely varying $\delta^{18} \mathrm{O}_{\text {ost }}$ values probably resulted from a combination of factors including changes in saline water input as a result of rising sea-level in Galway Bay (O’Connell \& Molloy 2017), variation in $\delta^{18} \mathrm{O}_{\mathrm{P}}$ (and hence $\delta^{18} \mathrm{O}_{\mathrm{L}}$ ) and evaporative enrichment. The steady increase in $\delta^{13} \mathrm{C}_{\mathrm{ost}}$ values over the same period may reflect enhanced aquatic productivity coupled with an increasing input of DIC from seawater.

Interestingly, the $\delta^{18} \mathrm{O}$ record from An Loch Mór is broadly similar to that from Knockadoon South (KS), i.e. a profile from a marginal location in Lough Gur, a lake of 74 ha in Carboniferous limestone terrain (Ahlberg et al. 2001). However, a profile from an adjacent basin (there is considerable local variation in the bedrock and Quaternary geology; see www.gsi.ie), which has infilled and is now a bog (Red Bog), has given a curve that has generally distinctly higher $\delta^{18} \mathrm{O}$ values than the curves from other western Ireland sites including An Loch Mór but yet has equally low values during the Younger Dryas (Fig. 9). This suggests that factors, other than purely climatic, are operating for most of the time that result in large fluctuations not only in $\delta^{18} \mathrm{C}$ values which are known to be determined largely by local factors but also in $\delta^{18} \mathrm{O}$ values which are generally regarded as reflecting change at a regional level. A full understanding of the significance of these differences awaits availability of more detailed and chronologically well-constrained, stable-isotope records derived from lake sediments in Ireland and north-west Europe generally.

\section{Conclusions}


The stable-isotope record from An Loch Mór is a complex product of multiple controls. The bulk-carbonate oxygen-isotope time series is most likely a record of the $\delta^{18} \mathrm{O}$ of lake water in the epilimnion during the spring-summer calcification period, although the influence of detrital carbonate cannot be ruled out for the Younger Dryas interval. The $\delta^{18} \mathrm{O}$ of surface water, in turn, is a product of the $\delta^{18} \mathrm{O}$ of rainwater, inputs of marine water and evaporative enrichment. The ostracod-isotope time series is affected by largely the same factors, but since ostracods are benthic and probably formed in the deeper parts of the lake, their oxygen-isotope values are less likely to be influenced by evaporative enrichment of nearsurface water. They are also expected to have calcified at lower temperatures, having formed in deeper and cooler parts of the lake. These factors, coupled with positive offsets from oxygen-isotope equilibrium that are well known for ostracod carbonate, may explain the fact that $\delta^{18} \mathrm{O}_{\mathrm{ost}}$ values are generally more positive than corresponding $\delta^{18} \mathrm{O}_{\mathrm{c}}$ values. The carbon-isotope records are a function of DIC source (soil carbon versus bedrock carbon) and modification by aquatic productivity and carbonate dissolution within the lake.

Comparison with other records from western Ireland indicates that the oxygenisotope time series from An Loch Mór are a complex reflection of changing regional climate, catchment dynamics and sea level during the Holocene and also the later part of the Younger Dryas, whereas the carbon-isotope records are more site specific. Notwithstanding this complexity, the stable isotope records from An Loch Mór provide us with additional information about the climatic and environmental evolution of western Ireland during the Younger Dryas and Holocene. Changes in $\delta^{18} \mathrm{O}$ and $\delta^{13} \mathrm{C}$ at the transition from the Younger Dryas stadial into the Holocene suggest a sharp increase in atmospheric temperature coupled with expansion of initially grass-dominated and then shrubby vegetation, and soil development within the catchment. However, although similar changes are evident at other sites in western Ireland and elsewhere in north-west Europe, 
the influence of detrital carbonate on the isotopic records of An Loch Mór at the end of the Younger Dryas cannot be entirely ruled out. Variations in $\delta^{18} \mathrm{O}$ and $\delta^{13} \mathrm{C}$ for much of the Holocene reflect minor changes in the isotopic composition of rainfall and in aquatic productivity against a trend of rising sea-level, especially over the past 1000 years. Two very marked positive $\delta^{18} \mathrm{O}$ excursions centred on about 9300 and 8200 cal. a BP punctuate these general trends. Although excursions are seen in pollen and isotopic records from elsewhere in western Ireland at these times (especially during the well-known 8200-year event), the direction and magnitude of the isotopic changes at An Loch Mór are difficult to explain on the basis of our present understanding of how these changes are controlled in limnological contexts.

Acknowledgements. - This work was undertaken as part of the EU-funded project, TIMECHS (Timing and mechanisms of Holocene climate change in NW Europe; contract no. ENV4-CT97-0557). We are grateful to Richard L. Jones for his assistance with ostracod analysis, and TIMECHS partners for sharing and discussing their data. Stableisotope data were kindly made available by Aaron Diefendorf (Lough Inchiquin) and Nelleke van Asche (Fiddaun Lough). Challenging but constructive reviews from M. Kirby and an anonymous referee, together with editorial suggestions from Editor-in-Chief Jan Piotrowski, have helped us improve this paper.

Author Contributions. - JH and MO'C co-wrote the manuscript and prepared the figures. Analyses were carried out by $\mathrm{JH}$ (ostracods), ML (stable isotopes) and KM (pollen). Age modelling was undertaken by MO'C who also coordinated data collection. All authors contributed to editing the manuscript. 


\section{References}

Ahlberg, K., Almgren, E., Wright H. E., Jr. \& Ito E. 2001: Holocene stable-isotope stratigraphy at Lough Gur, County Limerick, western Ireland. Holocene 11, 367-372.

Ahlberg, K., Almgren, E., Wright, H.E., Jr., Ito, E. \& Hobbie, S. 1996: Oxygen-isotope record of Late-glacial climatic change in western Ireland. Boreas 25, 257-267.

van Asch, N., Lutz, A. F., Duijkers, M. C. H., Heiri, O., Brooks, S. J. \& Hoek, W. Z. 2012: Rapid climate change during the Weichselian Lateglacial in Ireland: chironomid-inferred summer temperatures from Fiddaun, Co. Galway. Palaeogeography Palaeoclimatology Palaeoecology 315, 1-11.

Bigg, G. R. \& Rohling, E. J. 2000: An oxygen isotope data set for marine waters. Journal of Geophysical Research-Oceans 105, 8527-8535.

Bronk Ramsey, C. 2009: Bayesian analysis of radiocarbon dates. Radiocarbon 51, 337360.

Chambers, F. M., Daniell, J. R. G., Hunt, J. B., Molloy, K. \& O’Connell, M., 2004:

Tephrostratigraphy of An Loch Mór, Inis Oírr, western Ireland: implications for Holocene tephrochronology in the northeastern Atlantic region. Holocene 14, 703-720.

Daley, T. J., Thomas, E. R. Holmes, J. A., Street-Perrott, F. A., Chapman, M. R., Tindall, J. C., Valdes, P. J., Loader, N. J., Marshall, J. D., Wolff, E. W., Hopley, P. J., Atkinson, T. C., Barber, K. E., Fisher, E. H., Robertson, I. \& Roberts, C. N. 2011: The 8200 yr BP cold event in stable isotope records from the North Atlantic region. Global and Planetary Change 79, 288-302.

Diefendorf A. F. \& Patterson W. P. 2005: Survey of stable isotope values in Irish surface waters. Journal of Paleolimnology 34, 257-269.

Diefendorf A. F., Patterson W. P., Mullins H. T., Tibert N. \& Martini, A. 2006: Evidence for high-frequency late Glacial to mid-Holocene $(16,800$ to 5500 cal yr B.P.) climate variability from oxygen isotope values of Lough Inchiquin, Ireland. Quaternary Research 65, 78-86.

Diefendorf, A. F., Patterson, W. P., Holmden, C. \& Mullins, H. T. 2008: Carbon isotopes of marl and lake sediment organic matter reflect terrestrial landscape change during the late Glacial and early Holocene (16,800 to 5,540 cal yr BP): a multiproxy study of lacustrine sediments at Lough Inchiquin, western Ireland. Journal of Paleolimnology 39, 101-115.

Drinan, T. J., O'Halloran, J. \& Harrison, S. S. C. 2013: Variation in the physico-chemical and biologicial characteristics between upland and lowland (Atlantic) blanket bog lakes in western Ireland. Biology and Environment 113, 67-91. 
Edwards, R. \& Craven, K. 2017: Relative sea-level change around the Irish coast. In Coxon, P., McCarron, S. \& Mitchell, F. (eds.): Advances in Irish Quaternary Studies, 181215, Atlantis Press, Amsterdam.

Eicher, U. 1979: Die ${ }^{18} \mathrm{O} /{ }^{16} \mathrm{O}$ - und ${ }^{13} \mathrm{C} /{ }^{12} \mathrm{C}$-Isotopenverhältnisse in spätglazialen Süsswasserkarbonaten und ihr Zusammenhang mit den Ergebnissen der Pollenanalyse. Ph.D. thesis, University of Bern, 205 pp.

Einsiedl, F. 2012: Sea-water/groundwater interactions along a small catchment of the European Atlantic coast. Applied Geochemistry 27, 73-80.

Feehan, J. 1994: The geology of the Aran Islands. In Waddell, J., O'Connell, J. W. \& Korff, A. (eds.): The Book of Aran. The Aran Islands, Co. Galway, 17-34. Tír Eolas, Kinvara.

Ghilardi, B. \& O'Connell, M. 2013: Early Holocene vegetation and climate dynamics with particular reference to the 8.2 ka event: pollen and macrofossil evidence from a small lake in western Ireland. Vegetation History and Archaeobotany 22, 99-11.

Hammarlund, D., Barnekow, L., Birks, H. J. B., Buchardt, B. \& Edwards, T. W. D. 2002: Holocene changes in atmospheric circulation recorded in the oxygen-isotope stratigraphy of lacustrine carbonates from northern Sweden. Holocene 12, 339-351.

Holmes, J. A. \& Chivas, A. R. 2002. Ostracod shell chemistry - overview. In Holmes, J. A. \& Chivas, A. R. (eds.): The Ostracoda: Applications in Quaternary Research, 185-204. American Geophysical Union Geophysical Monograph 131.

Holmes, J. A., Jones, R. L., Haas, J. N., McDermott, F., Molloy, K. \& O'Connell, M. 2007: Multi-proxy evidence for Holocene lake-level and salinity changes at An Loch Mór, a coastal lake on the Aran Islands, western Ireland. Quaternary Science Reviews 26, 24382462.

Holmes, J. A., Tindall, J., Roberts, N., Marshall, W., Marshall, J. D. Bingham, A., Feeser, I., O'Connell, M., Atkinson, T., Jourdan, A-L., March, A. \& Fisher, E. H. 2016: Lake isotope records of the 8200-year cooling event in western Ireland: comparison with model simulations. Quaternary Science Reviews 131, 341-349.

Huber, C., Leuenberger, M., Spahni, R., Fluckiger, J., Schwander, J., Stocker, T. F., Johnsen, S., Landals, A. \& Jouzel, J. 2006: Isotope calibrated Greenland temperature record over Marine Isotope Stage 3 and its relation to $\mathrm{CH}_{4}$. Earth and Planetary Science Letters 243, 504-519.

Johansson, H., Lind, E. M. \& Wastegård, S. 2017: Compositions of glass in proximal tephras from eruptions in the Azores archipelago and their links with distal sites in Ireland. Quaternary Geochronology 40, 120-128.

Keatings, K. W., Heaton, T. H. E. \& Holmes, J. A. 2002: Carbon and oxygen isotope fractionation in non-marine ostracods: results from a 'natural culture' environment. Geochimica et Cosmochimica Acta 66, 1701-1711. 
Kelts, K. \& Talbot, M. 1990: Lacustrine carbonates as geochemical archives of environmental change and biotic/abiotic interactions. In Tilzer, M. M. \& Serruya, C. (Eds.): Large Lakes: Ecology, Structure and Function, 288-315. Springer, Dordrecht.

Kim, S. T. \& O'Neil, J. R. 1997: Equilibrium and nonequilibrium oxygen isotope effects in synthetic carbonates. Geochimica et Cosmochimica Acta 61, 3461-3475.

Kindler, P., Guillevic, M., Baumgartner, M., Schwander, J., Landais, A. \& Leuenberger, M. 2014: Temperature reconstruction from 10 to $120 \mathrm{kyr} b 2 \mathrm{k}$ from the NGRIP ice core.

Climate of the Past 10, 887-902.

Leng, M. J. \& Marshall, J. D. 2004: Palaeoclimate interpretation of stable isotope data from lake sediment archives. Quaternary Science Reviews 23, 811-831.

Leng, M. J., Lamb, A. L., Heaton, T. H. E., Marshall, J. D., Wolfe, B. B., Jones, M. D., Holmes, J. A. \& Arrowsmith, C. 2006: Isotopes in lake sediments. In Leng, M. J. (ed.): Isotopes in Palaeoenvironmental Research, 147-184, Springer, Dordrecht.

Marshall, J. D., Lang, B., Crowley, S. F., Weedon, G. P., van Calsteren, P., Fisher, E. H., Holme, R., Holmes, J. A., Jones, R. T., Bedford, A., Brooks, S. J., Bloemendal, J., Kiriakoulakis, K., Ball, J. D. 2007: Terrestrial impact of abrupt changes in the North Atlantic thermohaline circulation: Early Holocene, UK. Geology 35, 639-642.

McKenzie, J. A. 1985: Carbon isotopes and productivity in the lacustrine and marine environment. In Stumm, W. M. (ed.): Chemical Processes in Lakes, 99-118. Wiley Interscience, New York.

Meisch, C. 2000: Freshwater Ostracoda of Western and Central Europe. Süßwasserfauna von Mitteleuropa 8/3. 522 pp. Gustav Fischer, Stuttgart.

Mitchell, F. \& Ryan, M. 1997: Reading the Irish Landscape. 392 pp. Town House and Country House, Dublin.

Mitchell, G. F. 1951: Studies in Irish Quaternary deposits: No. 7. Proceedings of the Royal Irish Academy 53B, 111-206.

Molloy, K. \& O'Connell, M. 2004: Holocene vegetation and land-use dynamics in the karstic environment of Inis Oírr, Aran Islands, western Ireland: pollen analytical evidence evaluated in the light of the archaeological record. Quaternary International 113, 41-61.

Molloy, K. \& O'Connell, M. 2007: Fresh insights into long-term environmental change on the Aran Islands based on palaeoecological investigations of lake sediments from Inis Oírr. Journal of the Galway Archaeological and Historical Society 59, 1-17.

Molloy, K. \& O'Connell M. 2014: Post-glaciation plant colonisation of Ireland: fresh insights from An Loch Mór, Inis Oírr, western Ireland. In Sleeman, D. P., Carlsson, J. \& Carlsson, J. E. L. (eds.): Mind the Gap II: New Insights into the Irish Postglacial, 66-88. Irish Naturalists' Journal, Belfast. 
O'Connell, M. \& Molloy, K. 2017: Mid and late Holocene environmental change in western Ireland: new evidence from coastal peats and fossil timbers with particular reference to relative sea-level change. Holocene $27,825-1845$.

O’Connell, M. \& Molloy, K. 2019: Aran Islands, western Ireland: farming history and environmental change reconstructed from field surveys, historical sources, and pollen analyses. Journal of the North Atlantic 38, 1-27.

O’Connell, M., Huang, C. C. \& Eicher, U. 1999. Multidisciplinary investigations, including stable-isotope studies, of thick late-glacial sediments from Tory Hill, Co. Limerick, western Ireland. Palaeogeography Palaeoclimatology Palaeoecology 147, 169-208.

Paus, A., Haflidason, H., Routh, J., Naafs, B. D. A. \& Thoen, M. W. 2019: Environmental responses to the 9.7 and 8.2 cold events at two ecotonal sites in the Dovre mountains, mid-Norway. Quaternary Science Reviews 205, 45-61.

Peters, J. L., Benetti, S., Dunlop, P. \& Ó Cofaigh, C. 2015: Maximum extent and dynamic behaviour of the last British-Irish ice sheet west of Ireland. Quaternary Science Reviews 128, 48-68.

Plunkett, G. \& Pilcher, J. R. 2018: Defining the potential source region of volcanic ash in northwest Europe during the Mid- to Late Holocene. Earth-Science Reviews 179, $20-37$.

Rasmussen, S. O., Bigler, M., Blockley, S. P., Blunier, T., Buchardt, S. L., Clausen, H. B., Cvijanovic, I., Dahl-Jensen, D., Johnsen, S. J., Fischer, H., Gkinis, V., Guillevic, M., Hoek, W. Z., Lowe, J. J., Pedro, J. B., Popp, T., Seierstad, I. K., Steffensen, J. P., Svensson, A. M., Vallelonga, P., Vinther, B. M., Walker, M. J. C., Wheatley, J. J. \& Winstrup, M. 2014: A stratigraphic framework for abrupt climatic changes during the Last Glacial period based on three synchronized Greenland ice-core records: refining and extending the INTIMATE event stratigraphy. Quaternary Science Reviews 106, 14-28.

Reimer, P. J., Bard, E., Bayliss, A., Beck, J. W., Blackwell, P. G., Bronk Ramsey, C., Buck, C. E., Cheng, H., Edwards, R. L., Friedrich, M., Grootes, P. M., Guilderson, T. P., Haflidason, H., Hajdas, I., Hatté, C., Heaton, T. J., Hoffmann, D. L., Hogg, A. G., Hughen, K. A., Kaiser, K. F., Kromer, B., Manning, S. W., Niu, M., Reimer, R. W., Richards, D. A., Scott, E. M., Southon, J. R., Staff, R. A., Turney, C. S. M. \& van der Plicht, J. 2013: IntCal13 and Marine13 radiocarbon age calibration curves $0-50,000$ years cal BP. Radiocarbon 55, 1869-1887.

Romanek, C. S., Grossman, E. L. \& Morse, J. W. 1992: Carbon isotopic fractionation in synthetic aragonite and calcite: effects of temperature and precipitation rate. Geochimica et Cosmochimica Acta 56, 419-430.

Rozanski, K., Araguás-Araguás, L. \& Gonfiantini, R. 1993: Isotopic patterns in modern global precipitation. In Swart, P. K., Lohmann, K. C., McKenzie, J. \& Savin, S. (Eds.): Climate Change in Continental Isotopic Records, 1-36. American Geophysical Union Geophysical Monograph 78. 
Schettler, G. \& Romer, R. L. 2006: Atmospheric Pb-pollution by pre-medieval mining detected in the sediments of the brackish karst lake An Loch Mór, western Ireland. Applied Geochemistry 21, 58-82.

Schettler, G., Romer, R., O'Connell, M. \& Molloy, K. 2006: Holocene climatic variations and postglacial sea-level rise geochemically recorded in the sediments of the brackish karst lake An Loch Mór, western Ireland. Boreas 35, 674-692.

Shennan, I., Bradley, S. L. \& Edwards, R. 2018: Relative sea-level changes and crustal movements in Britain and Ireland since the Last Glacial Maximum. Quaternary Science Reviews 188, 143-159.

Smith, B. N. \& Epstein, S. 1971: Two categories of ${ }^{13} \mathrm{C} /{ }^{12} \mathrm{C}$ ratios for higher plants. Plant Physiology 47, 380-384.

Tibert, N. E., Patterson, W. P., Diefendorf, A. F., Martini, A. \& Stanton, C. 2007: Holocene temperature variability in western Ireland: evidence from limnic ostracode assemblages and stable isotope values. Stratigraphy 4, 353-361.

TIMECHS 2001: TIMECHS: Timing and mechanisms of Holocene climate change in NW Europe. Final reports of contractors and associates. EU, 4th Framework Programme (phase 2), Climate and Environment. 2 volumes.

Troels-Smith, J. 1955: Karakterisering af løse jordarter. Characterization of unconsolidated sediments. Danmarks Geologiske Undersøgelse, IV.Raekke 3, 1-73.

Waddell, J. 2010: The Prehistoric Archaeology of Ireland. 455 pp. Wordwell, Bray.

Walker, M., Johnsen, S., Rasmussen, S. O., Popp, T., Steffensen, J-P., Gibbard, P., Hoek, W., Lowe, J., Andrews, J., Björck, S., Cwynar, L. C. Hughen, K., Kershaw, P., Kromer, B., Litt, T., Lowe, D. J., Nakagawa, T., Newnham, R. \& Schwander, J. 2009: Formal definition and dating of the GSSP (Global Stratotype Section and Point) for the base of the Holocene using the Greenland NGRIP ice core, and selected auxiliary records. Journal of Quaternary Science 24, 3-17.

Walsh, S. 2012: A Summary of Climate Averages for Ireland 1981-2010. Climatological Note No. 14. 15 pp. Met Éireann, Dublin.

Zeebe, R. \& Wolf-Gladrow, D. 2001: $\mathrm{CO}_{2}$ in Seawater: Equilibrium, Kinetics, Isotopes. 346 pp. Oceanography Book Series 65. Elsevier, Amsterdam.

Zhang, J., Quay, P. D. \& Wilbur, D. O. 1995: Carbon-isotope fractionation during gaswater exchange and dissolution of $\mathrm{CO}_{2}$. Geochimica et Cosmochimica Acta 59, 107-114. 


\section{List of figures}

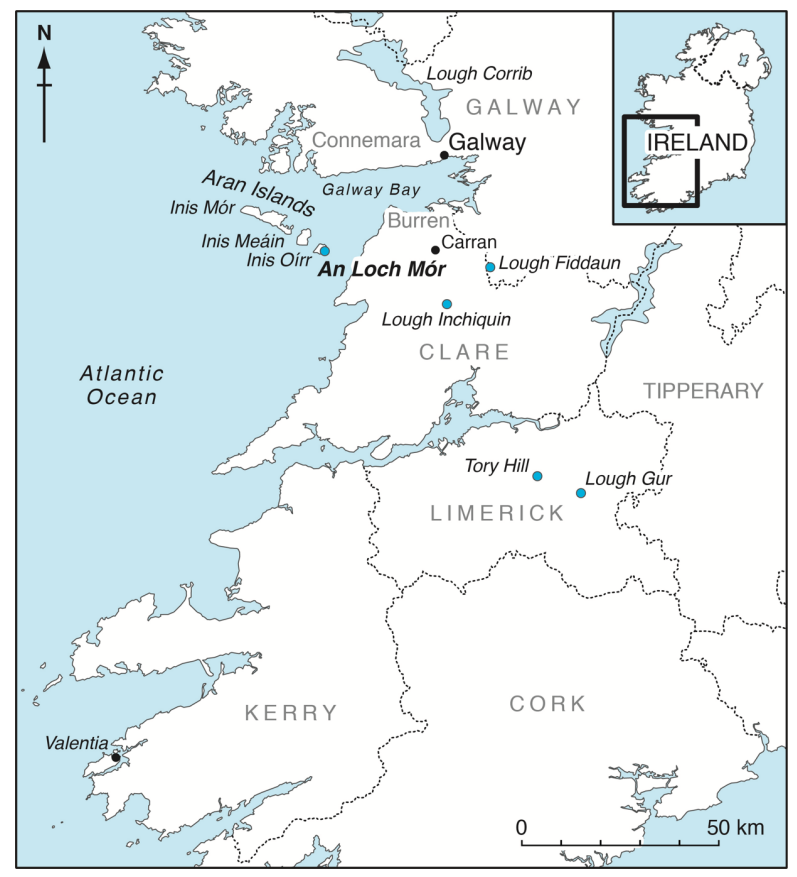

Fig 1. Location of An Loch Mór and other sites in western Ireland referred to in the text. 


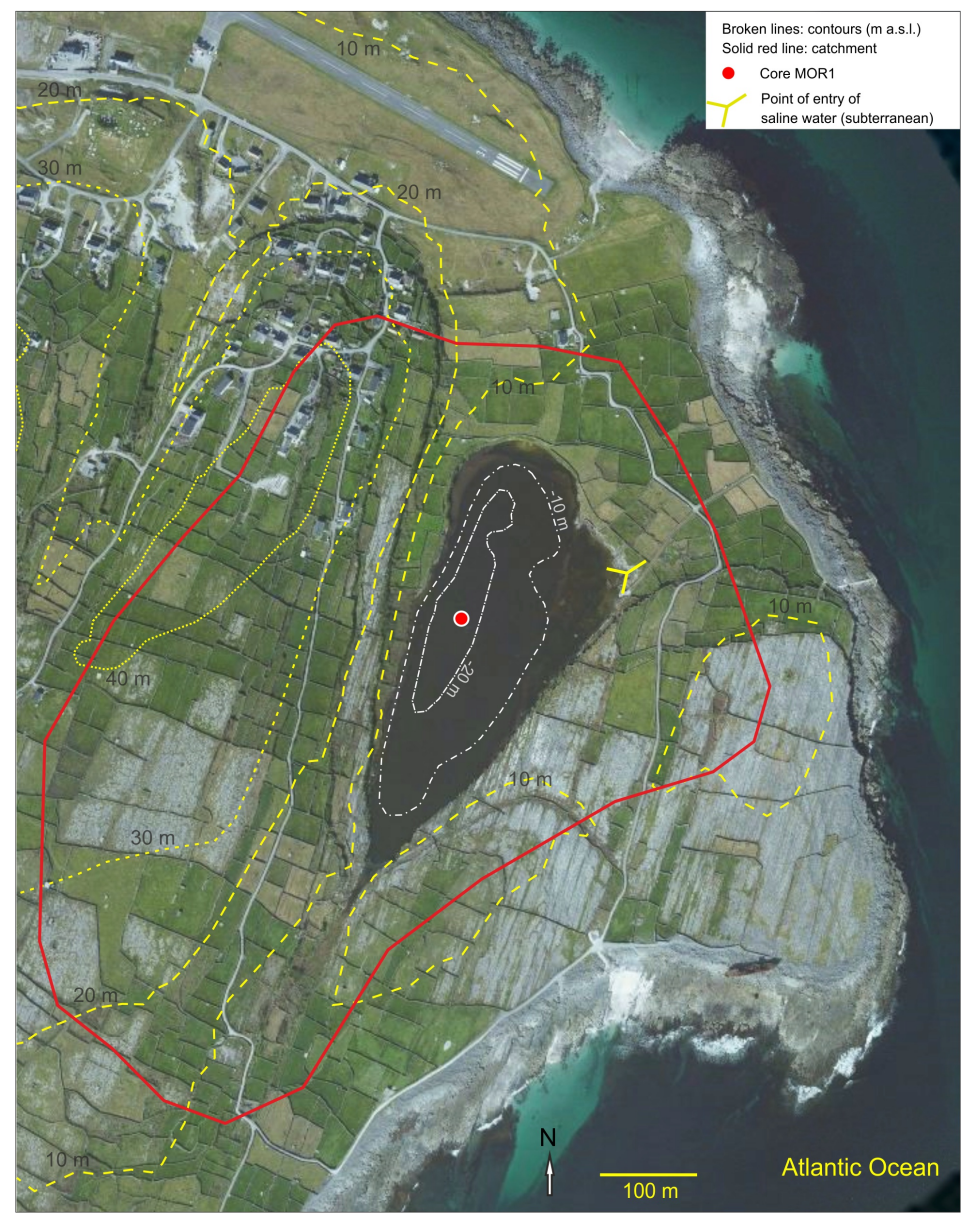

Fig. 2. Aerial photograph (Bing Maps; (C) Microsoft; accessed 23 August 2019) of eastern part of Inis Oírr including An Loch Mór (6.5 ha). The catchment ( 36.5 ha) consists mainly of small, stone-wall enclosed fields under pasture (smaller fields especially were intensively cultivated up to 1950s) and considerable areas of exposed karst. Land and lake-sediment contours are indicated by positive and negative values (10 m a.s.I. intervals), respectively. Land contours are based on Ordnance Survey of Ireland data (available at: http://map.geohive.ie/mapviewer.html; accessed 23 August 2019). Lake-sediment contours are derived from water depths as measured in summer 1997; it is assumed that the lakewater surface was at $0 \mathrm{~m}$ a.s.I. Location of core MOR1 is indicated. Lake-water profiling (see text) was carried out in this part of the lake, i.e. where maximum water depth was recorded. Diurnal entry (subterranean through the jointed limestone) of saline waters is evident at point marked by a ' $Y$ '. 


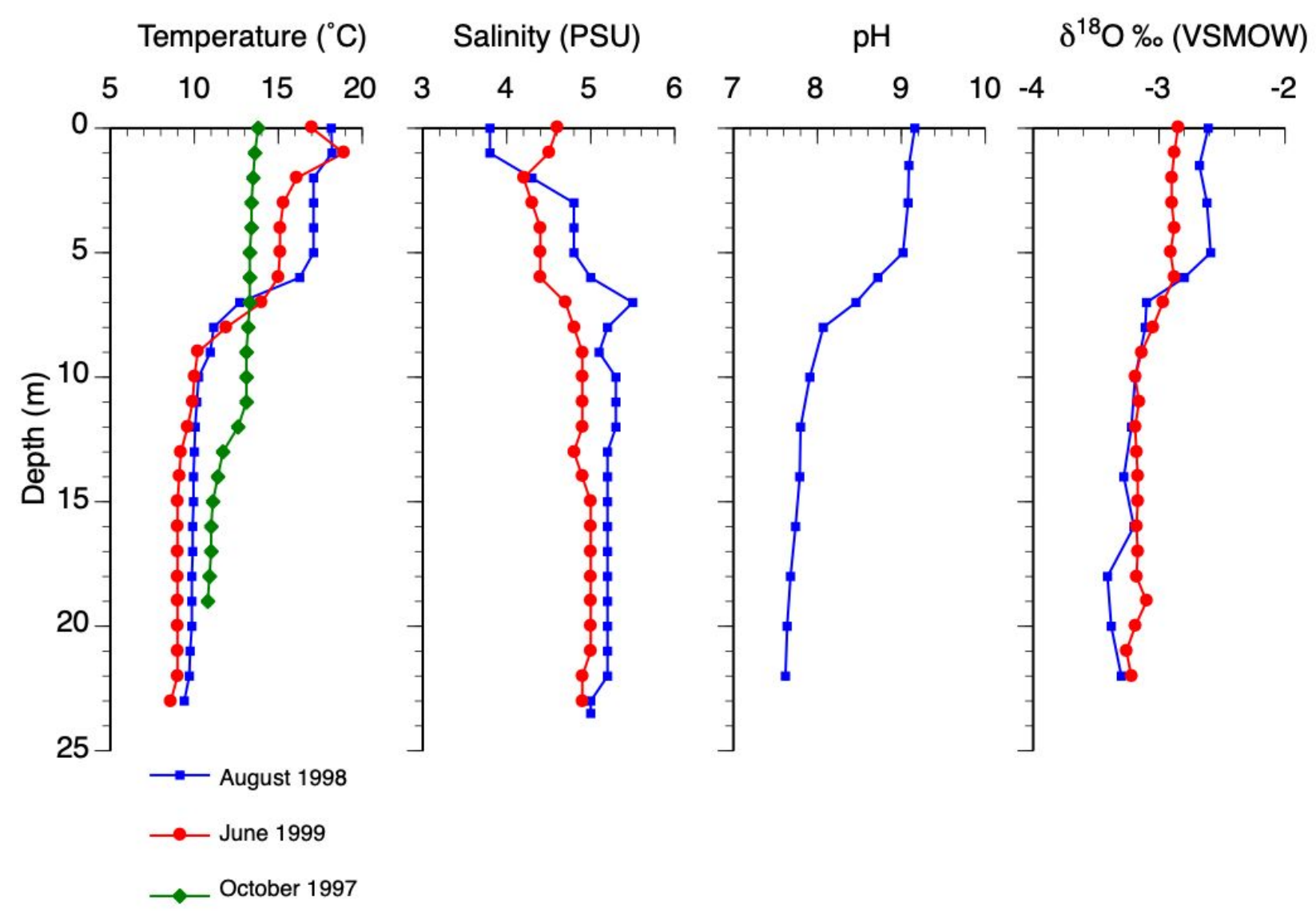

Fig. 3. Oxygen isotopes and other limnological variables in the water column of An Loch Mór. Non-isotope data from Holmes et al. (2007). 


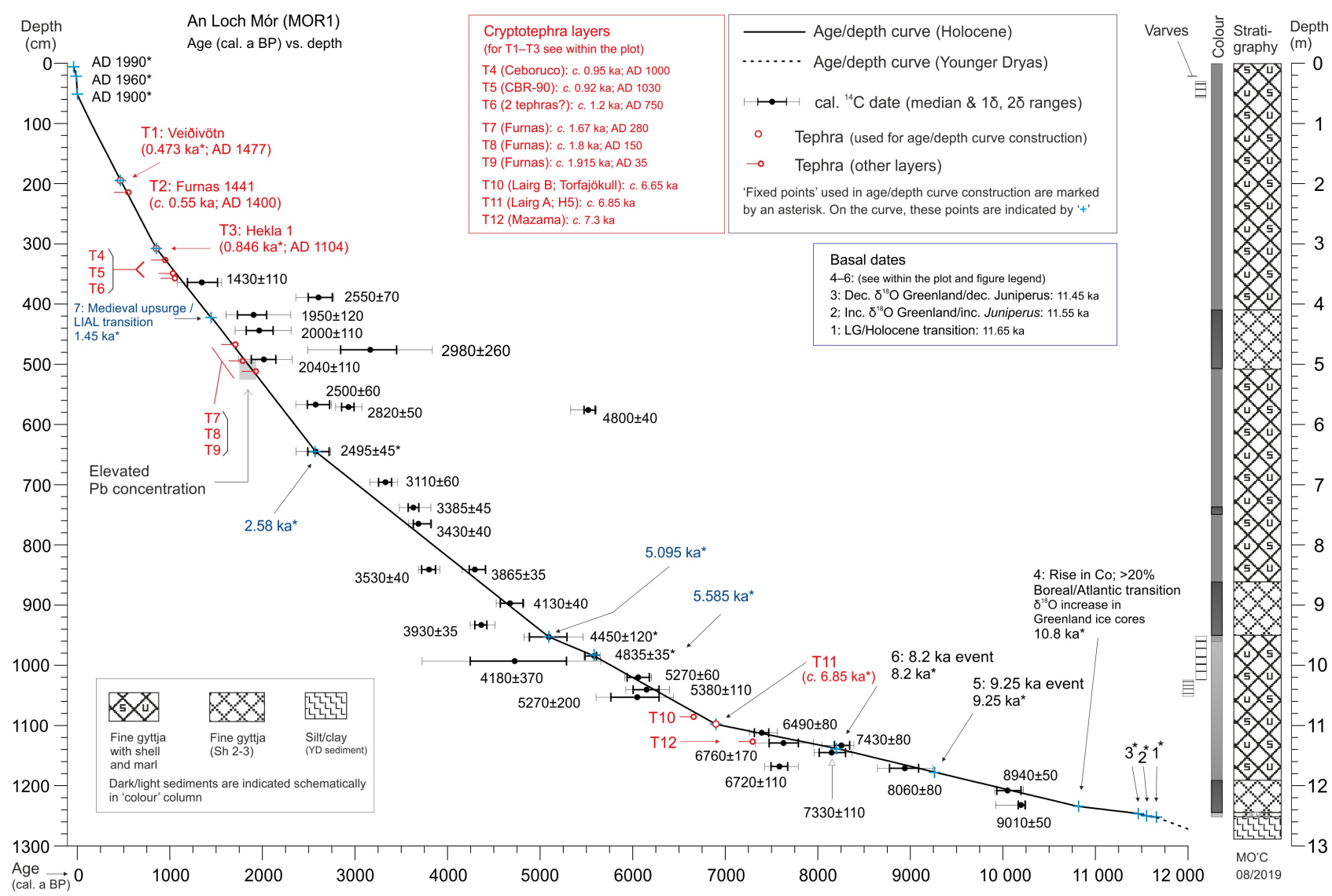

Fig. 4. Age/depth curve for profile MOR1, An Loch Mór, Inis Oírr. This curve has been used in all publications relating to An Loch Mór since 2012 when the curve was constructed. Calibrated median ages of ${ }^{14} \mathrm{C}$ dates that were used as 'fixed points' (three in all) are indicated by a blue font. New information regarding the origin of cryptotephra layers (red) is shown on the figure (but the age/depth curve is as drafted in 2012; the new information supports the model). The age/depth curve consists of straight-line segments joining the various 'fixed points' (age indicated and labelled ka, i.e. cal. a BP in 1000s years). 'Fixed points' used in curve construction are marked by an asterisk. Stratigraphy is indicated following the Troels-Smith (1955) scheme. Features used to construct the age/depth model include: (i) Calibrated AMS ${ }^{14} \mathrm{C}$ dates (31 dates in all; by J. van der Plicht, Centre for Isotope Research, Groningen) including the median age, and $1 \sigma$ and $2 \sigma$ age ranges derived from calibration using OxCal 4.3 (Bronk Ramsey 2009) and the default ${ }^{14} \mathrm{C}$ calibration curve, IntCal13.14C (Reimer et al. 2013). Dates from the upper part of the core are much older 
than expected ('age reversal') and so are rejected. Otherwise, the ${ }^{14} \mathrm{C}$ dates generally support the proposed chronology. Several of the dates are not directly used in curve construction as this would imply rapid changes in sedimentation rates that are regarded as unrealistic. (ii) Cryptotephra layers (Chambers et al. 2004; information provided by Plunkett \& Pilcher (2018) and Johansson et al. (2017) also shown). Cryptotephra layers used to provide 'fixed-points' are as follow: in the upper part of the profile, Veiðivötn (AD 1477) and Hekla 1 (AD 1104; this is the most pronounced Holocene tephra layer), i.e. T1 and T3 in Chambers et al. 2004; in the lower part, layer T11, which is geochemically comparable to Lairg A tephra and datable to c. 6900 cal. a BP (Chambers et al. 2004), is used. (iii) Dates 1-7. Date 1 is based on the age of the Lateglacial/Holocene transition as defined in Walker et al. (2009). This boundary is clearly and sharply defined in MOR1 on the basis of both pollen and lithology. Dates $2-6$ are based on the ages of substantial shifts in $\delta^{18} \mathrm{O}$ values in the Greenland ice cores (Rasmussen et al. 2008). It is assumed that major movements in the pollen curves of temperature-sensitive taxa - e.g. Juniperus and Corylus at 2-4; Corylus, Betula and Pinus at 5 and 6, i.e. 9.25 and 8.2 ka events (cf. Ghilardi \& O'Connell 2013; Paus et al. 2019) - coincide with these shifts (Molloy \& O'Connell 2014). Date 7, in the upper part of the profile, marks the boundary between the Late Iron Age Lull (LIAL) and increased farming impact in the early Medieval period, which is palynologically well defined. Its age is based on securely dated ${ }^{14} \mathrm{C}$-dated pollen profiles from western Ireland. (iv) the three calendar dates for the uppermost sediments rely on (a) ${ }^{210} \mathrm{~Pb}$-dating using the Constant Initial Concentration rate model $(\mathrm{ClC})$ and supported by ${ }^{137} \mathrm{Cs}$ date $(\mathrm{H}$. Heijnis in van der Plicht in TIMECHS 2001), (b) thick laminations (5-10 mm), presumably varves and most likely ascribable to lake enrichment due to increased input of domestic waste and use of artificial fertilisers starting in the early 1950s (TIMECHS 2001), and (c) expansion of Potamogeton sect. Coleogeton; this pollen taxon is assumed to consist almost exclusively of $P$. pectinatus pollen that has resulted from the expansion of this pondweed in the lake 
due to enrichment. The age/depth model is also supported by other features including (a) a Middle Holocene varved intervals $\left(1056-1026 \mathrm{~cm}: 1.5 \mathrm{~mm} \mathrm{a}^{-1}\right.$ (this includes turbidites; each turbidite is regarded as a year so that the accumulation rate is probably exaggerated); 1026 $953 \mathrm{~cm}: 0.87 \mathrm{~mm} \mathrm{a}^{-1}$ which is in good agreement with accumulation rates derived from the age/depth curve (T. Saarinen in TIMECHS 2001; also plate 2 in Molloy \& O'Connell 2007); and (b) elevated $\mathrm{Pb}$ levels in $525-495 \mathrm{~cm}$ that are most likely ascribable to Roman lead smelting (Schettler \& Romer 2006). According to the age-depth model, the latter sediment interval spans the first two centuries $A D$ which is as expected on historical grounds.

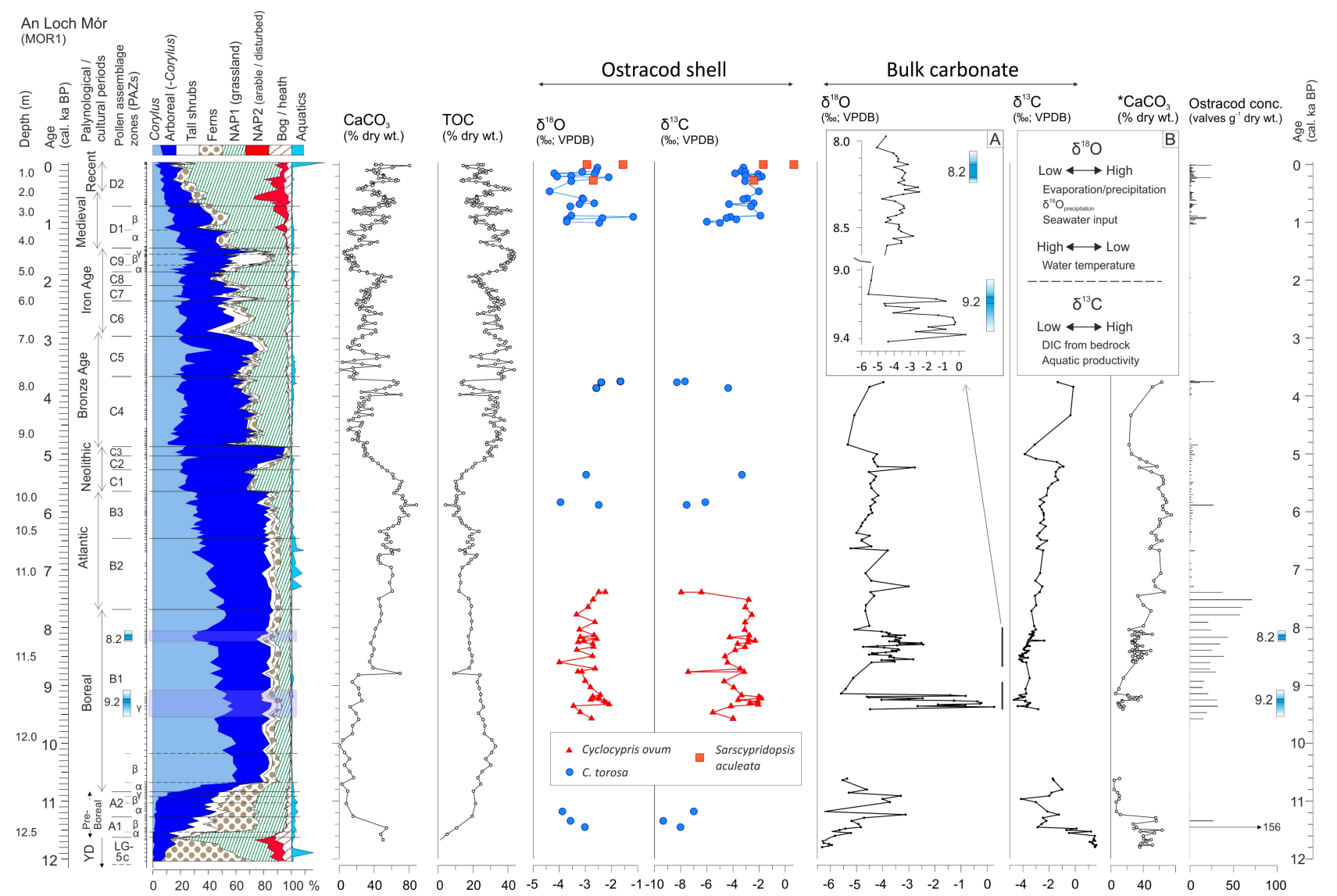


Fig. 5. Pollen and geochemical, including stable-isotope, data plotted to a calibrated time scale derived from the age/depth model (see Fig. 4). Depths are indicated with respect to the sediment/lake water interface. Details shown include: (i) Composite percentage pollen curves. Selected individual pollen percentage curves are given in Fig. S1 as well as details regarding the composite pollen groups. Palynological/cultural intervals (former as in Mitchell 1951; for latter see Waddell 2010 and Mitchell \& Ryan 1997), PAZs (Holocene PAZs are after Molloy \& O'Connell 2004; the basal samples are from the top of the Younger Dryas (YD) and are zoned with respect to the Lateglacial (LG-; not yet published), and the $8.2 \mathrm{ka}$ and 9.2 ka events (cf. Ghilardi \& O'Connell 2013; the overall duration and interval during which the event is most strongly expressed, based on the pollen data, are indicated. The Elm Decline and Neolithic Landnam, and the Late Iron Age Lull (LIAL; decrease in farming), are recorded at the base of PAZ C1 and in PAZ C9, respectively.

(ii) $\mathrm{CaCO}_{3}$ and TOC (total organic carbon) values are after Schettler et al. (2006). Stableisotope (SI) data derived from identified ostracod shell and bulk carbonate samples are shown. $\mathrm{CaCO}_{3}$ values as measured in samples that were analysed for stable isotopes are indicated by an asterisk. Ostracod valve concentration values are also shown. Data points (in the case of SI and related data) are joined by straight lines only where there are several samples over relatively short intervals.

(A) $\delta^{18} \mathrm{O}$ values (carbonate samples) relating to the $8.2 \mathrm{ka}$ and $9.2 \mathrm{ka}$ events (these events as reflected in the pollen data are indicated schematically; see above; also Fig. S1) on a magnified y axis. (B) Arrows showing most likely significance of movements in $\delta^{18} \mathrm{O}$ and $\delta^{13} \mathrm{C}$ curves (see also text). 

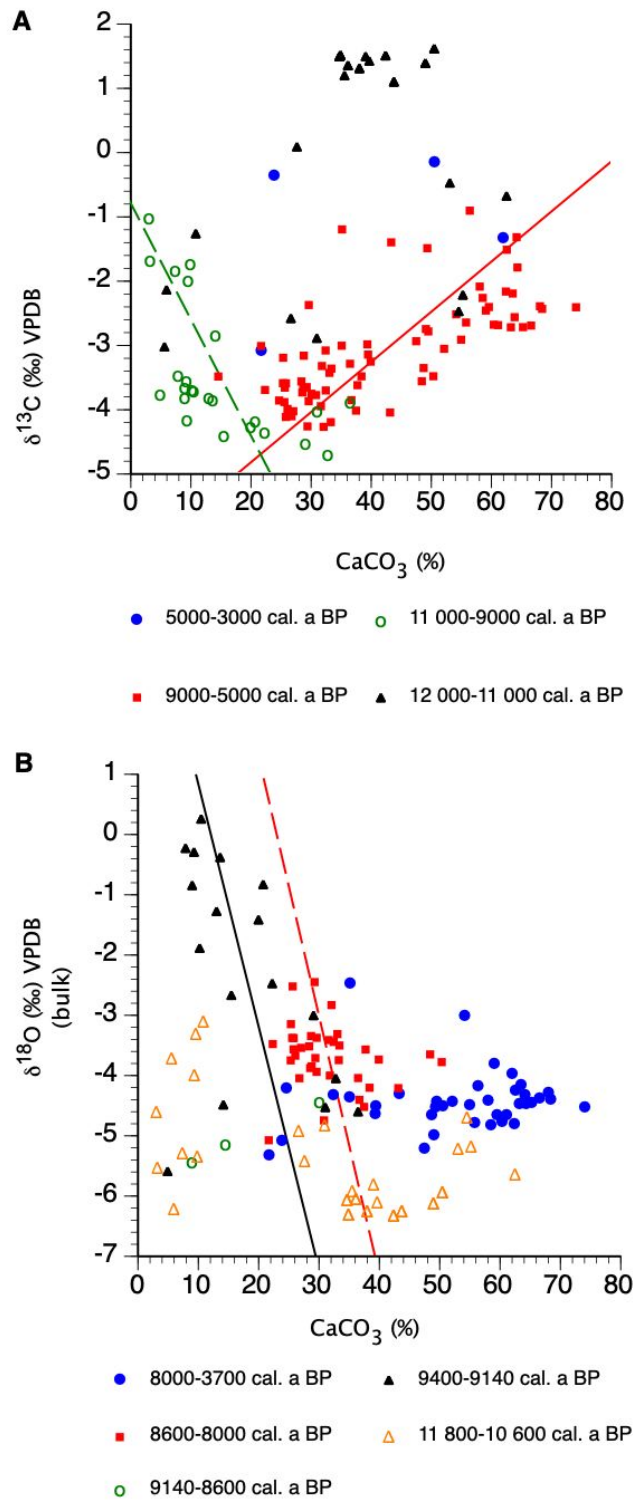

Fig. 6. A. Bulk carbonate $\delta^{13} \mathrm{C}$ versus percentage $\mathrm{CaCO}_{3}$. The linear regression lines are fitted to the data points from $11000-9000$ cal. a BP (green dashed: $\mathrm{R}^{2}=0.36, \mathrm{n}=24, P=$ 0.002 ) and to data points from $9000-5000$ cal. a BP (red solid: $\mathrm{R}^{2}=0.47, \mathrm{n}=73, P<0.001$ ). B. Bulk carbonate $\delta^{18} \mathrm{O}$ versus percentage $\mathrm{CaCO}_{3}$. The linear regression lines are fitted to the data points from $9400-9140$ cal. a BP (black solid: $R^{2}=0.22, n=17, P=0.055$ ) and to data points from $8600-8000$ cal. a BP (red dashed: $\mathrm{R}^{2}=0.04, \mathrm{n}=36, P=0.273$ ). 


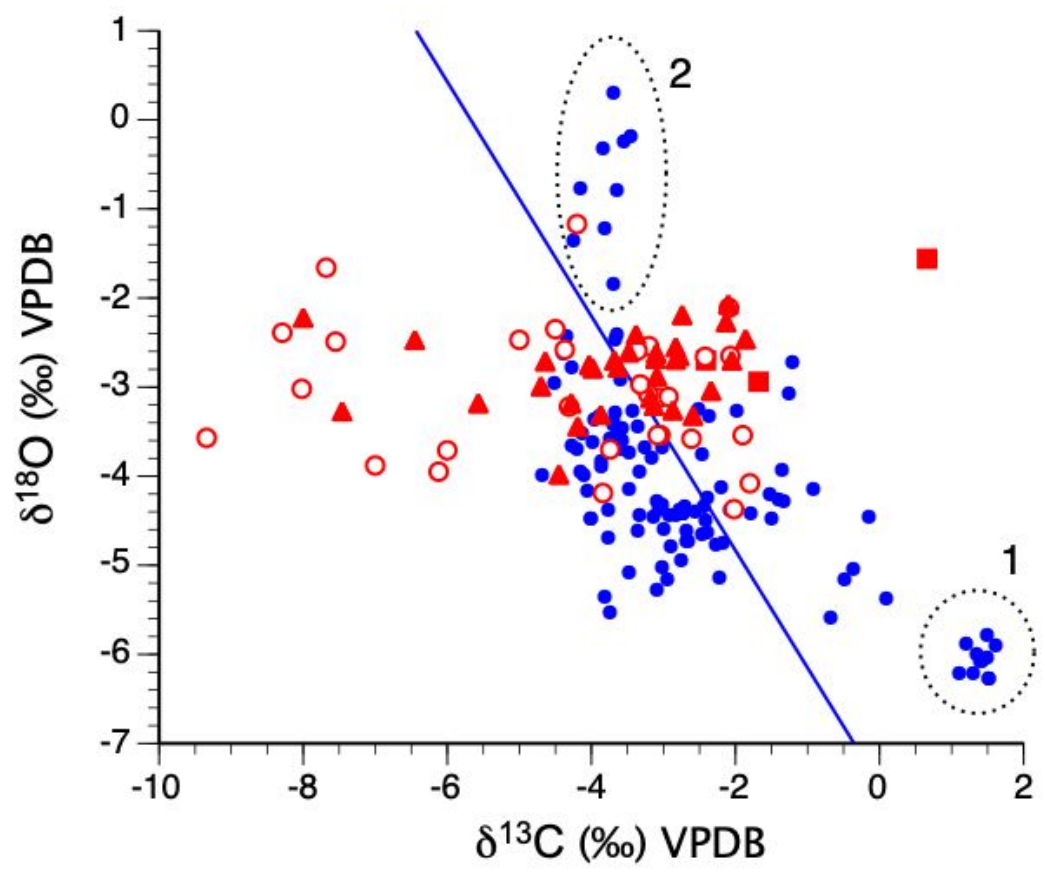

- Bulk carbonate

- Cyprideis torosa

- Sarscypridopsis aculeata

- Cyclocypris ovum

Fig. 7. Covariance plot of bulk and ostracod $\delta^{13} \mathrm{C}$ versus bulk and ostracod $\delta^{18} \mathrm{O}$. For the bulk carbonate data, the interval marked 1 , i.e. the earliest part of the record until $c$. 11600 cal. a BP, has low $\delta^{18} \mathrm{O}$ and high $\delta^{13} \mathrm{C}$ values while samples relating to interval 2 (9400-9200 cal. a BP), have mainly high $\delta^{18} \mathrm{O}$ and rather low $\delta^{13} \mathrm{C}$ values. For the bulk carbonate data, $\left.\mathrm{R}^{2}=0.38, P<0.001\right)$ 


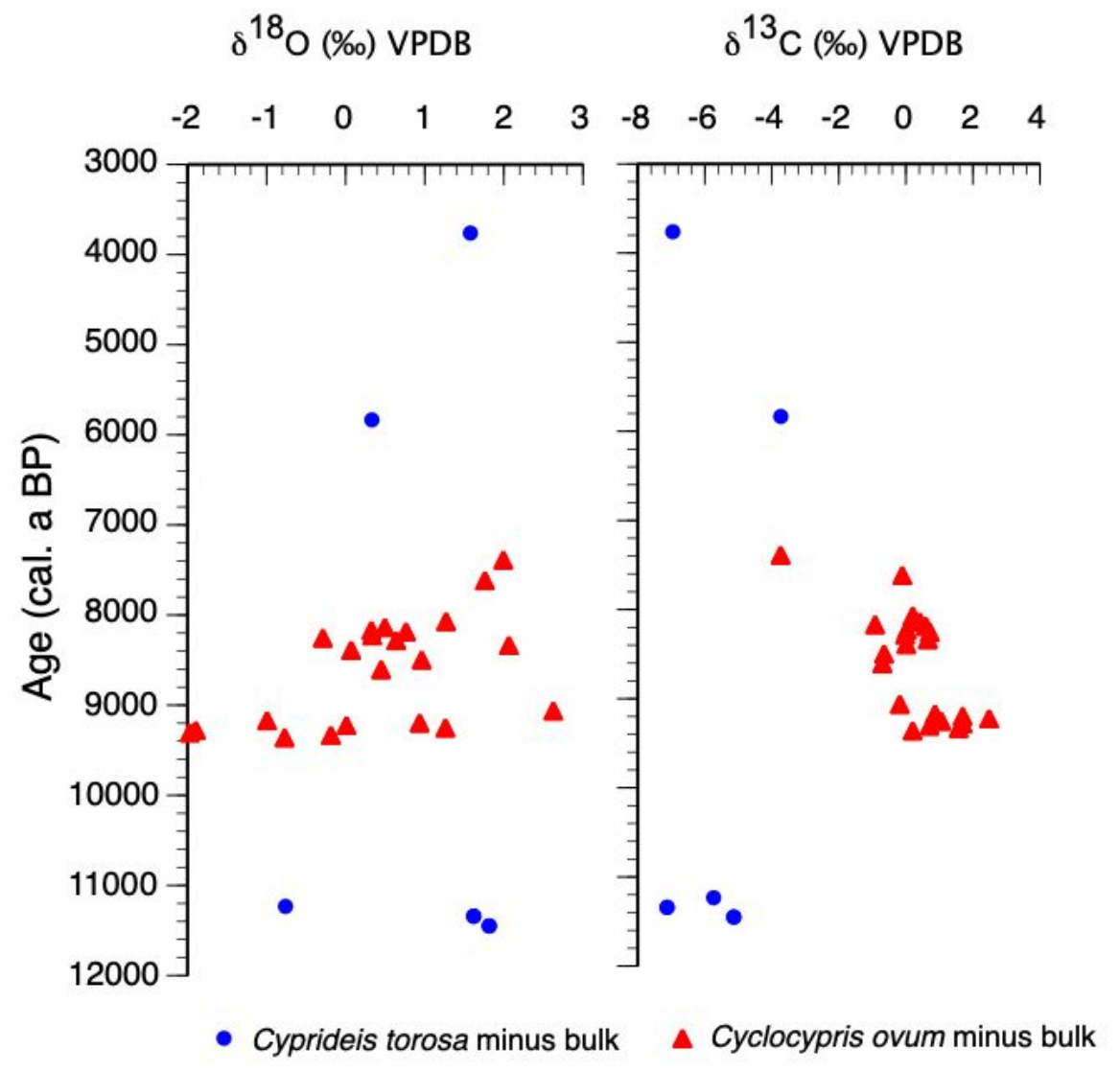

Fig. 8. Difference between bulk carbonate and ostracod carbonate $\delta^{13} \mathrm{C}$ and $\delta^{18} \mathrm{O}$ values for depths in core MOR1 where both fractions were analysed. 


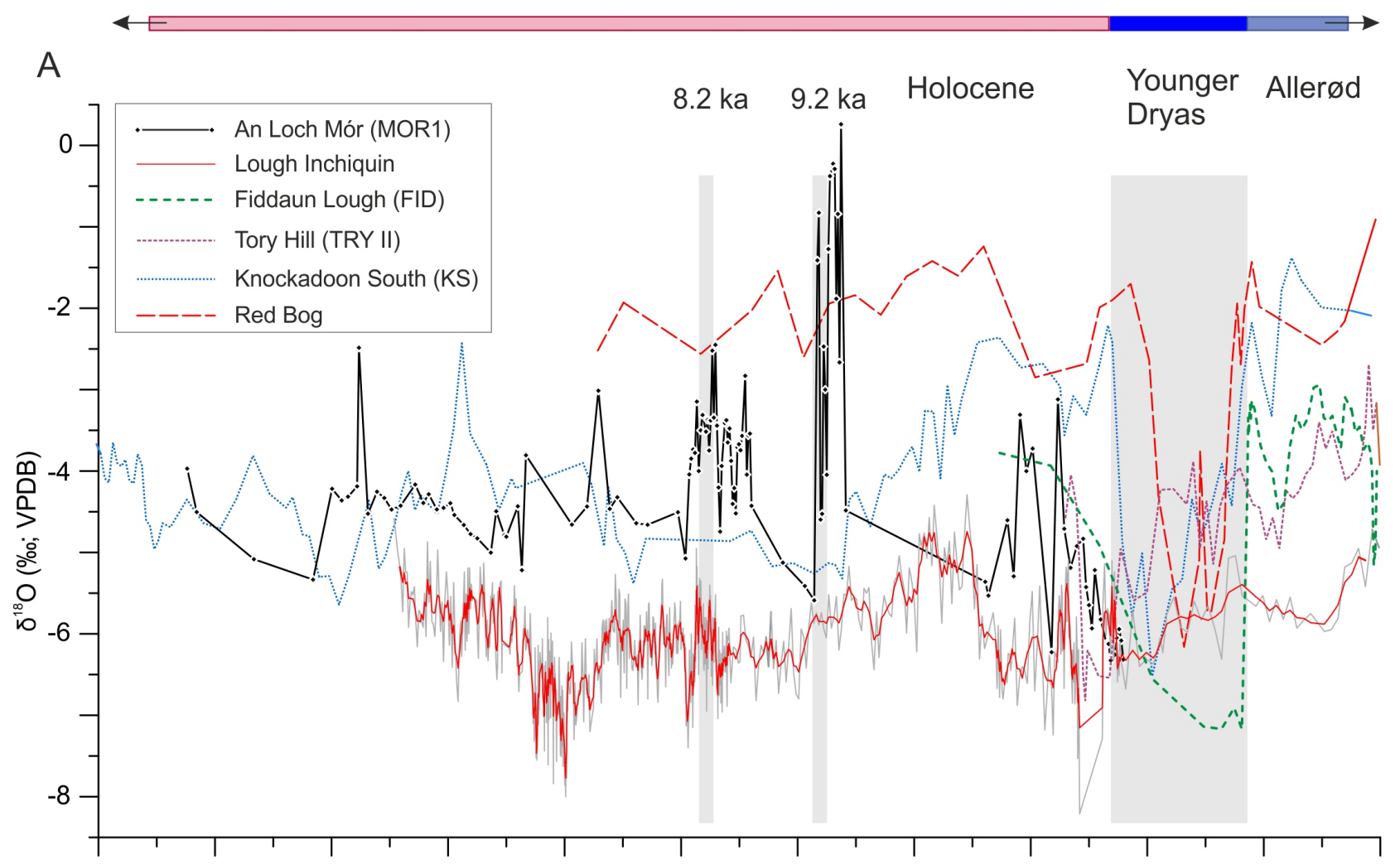

B

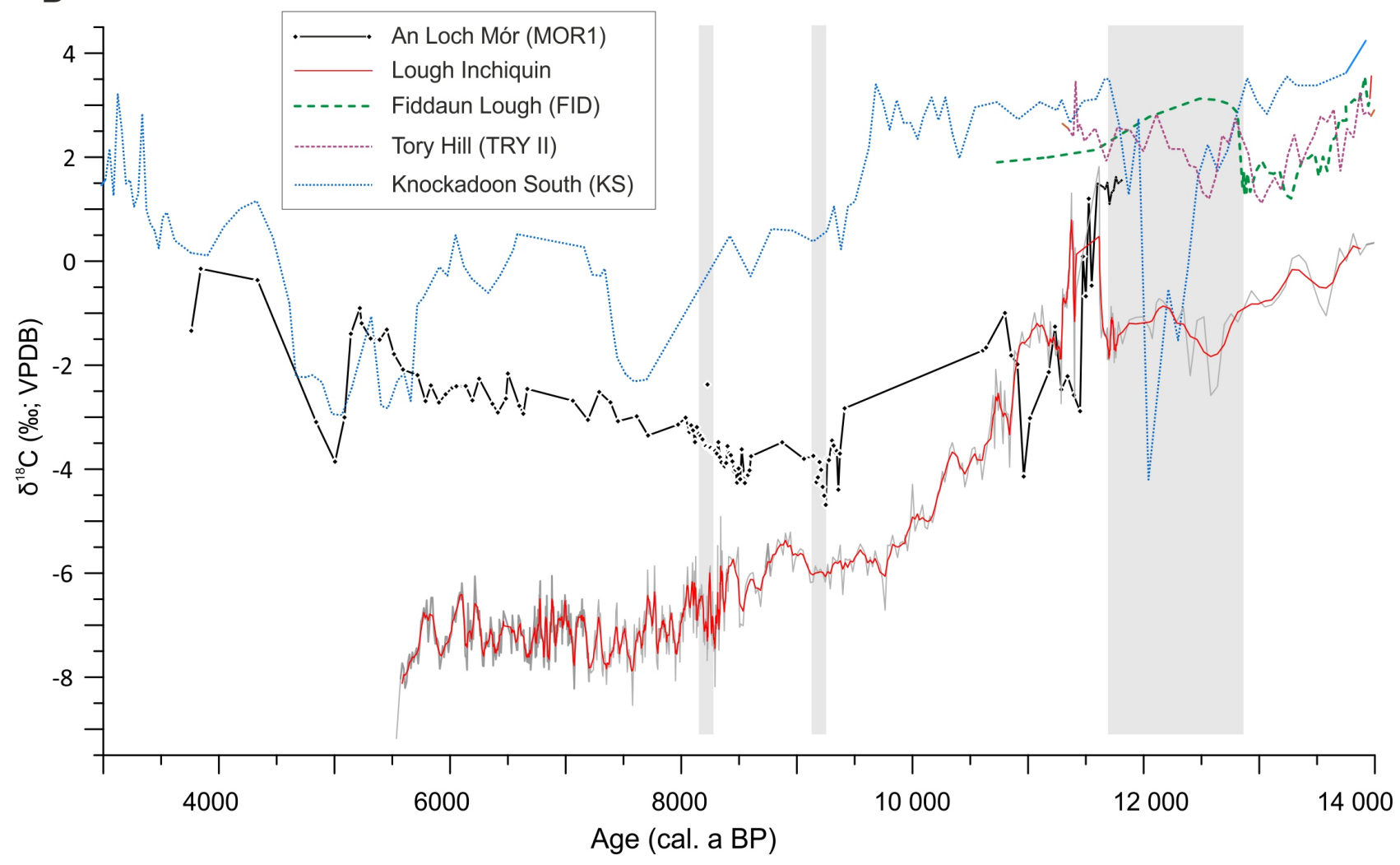

Fig. 9. Intersite comparison of stable isotope data (A. $\delta^{13} \mathrm{C}$ and B. $\left.\delta^{18} \mathrm{O}\right)$ for the interval 14 3 cal. ka BP (late Allerød to the Middle/Late Holocene) from selected sites in western Ireland. An Loch Mór data are as presented here. Knockadoon South (KS) (from Lough Gur) and nearby Red Bog $\left(\delta^{13} \mathrm{C}\right.$ data not available) data are after Ahlberg et al. (1996, 
2001). The chronology is based on the published ${ }^{14} \mathrm{C}$ dates (linear interpolation between the calibrated dates). Ahlberg et al. (2001) suggest that there may be a hiatus during the Middle Holocene in the KS profile. Tory Hill data are from O'Connell et al. (1999) and Lough Inchiquin data are from Diefendorf et al. $(2006,2008)$. Both are plotted using the original published timescales. In the case of L. Inchiquin, a five-point weighted mean (central points weighted $x 2$ relative to the other points) is shown on a background curve that shows results for individual samples. Shading is used to highlight the Younger Dryas stadial (dating after Rasmussen et al. 2014) and to indicate when the $9.2 \mathrm{ka}$ and $8.2 \mathrm{ka}$ climate events would be expected in register in the stable isotope records.

\section{Supporting information}

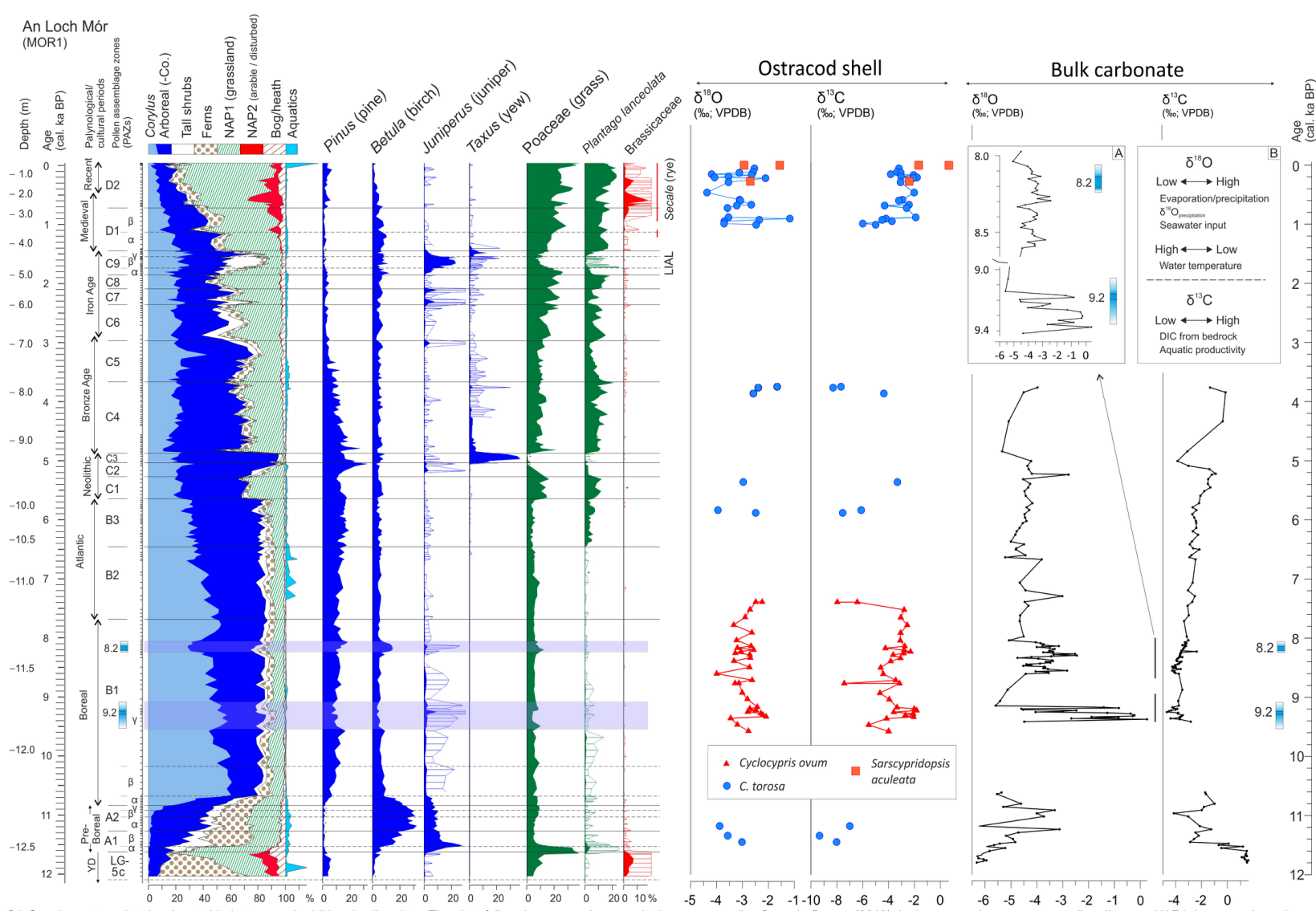

Fig. S1. Supplementary plot showing stable-isotope and additional pollen data. The plots follow the same scheme as in the corresponding figure in Boreas (2019). In the composite percentage pollen diagram, NAP1, i.e. non-arboreal Fig. S1. Supplementary plot showing stable-isotope and additional pollen data. The plots follow the same scheme as in the corresponding figure in Boreas (2019). In the composite percentage pollen diagram, NAP1, i.e. non-arboreal
pollen, group 1, consists mainly of Poaceae (grass) and $P$. lanceolata (ribwort plantain) pollen; NAP2 includes much Brassicaceae pollen (crucifers; indicative of disturbed habitats) in the basal and uppermost samples; additionally, cereatype pollen and especially Secale (rye) are common in the uppermost samples. Aquatics consist mainly of Potamogeton and Myriophyllum pollen; the spike at the top is indicative of recent (1950s onwards) lake-water enrichment. Individual pollen curves of key indicative (disturbance attributable to climate change and/or human impact in the upper half of the record) are provided. Silhouettes show pollen percentage values magnified $x 10$. Stable-isotope (SI) data from identified ostracod shell and bulk carbonate samples are shown. Inset A shows $\delta^{18} \mathrm{O}$ values (carbonate samples) relating to the $8.2 \mathrm{ka}$ and $9.2 \mathrm{ka}$ events
movements in $\delta^{18} \mathrm{O}$ and $\delta^{13} \mathrm{C}$ curves. Pollen data: K. Molloy; stable-isotope data: J. Holmes (ostracod) and M. Leuenberger (bulk carbonate) : graphics: M. O'Connel.

Fig. S1 Stable-isotope and additional pollen data from core MOR1. 


\begin{tabular}{|c|c|c|c|c|c|c|c|c|c|c|c|}
\hline & & & & & & & & & & & \\
\hline \multirow[t]{3}{*}{ Depth (m) } & 21-Aug-98 & & & & & & 01-Jun-99 & & & & Oct-97 \\
\hline & Temp & Dissolved Oxygen & Salinity & Kcorr & $\mathrm{pH}$ & $\delta^{18} \mathrm{O}$ & Temp & Salinity & Kcorr & $\delta^{18} \mathrm{O}$ & Temp \\
\hline & ${ }^{\circ} \mathrm{C}$ (average) & $\mathrm{mg} / \mathrm{L}$ & $\%$ & $(\mu \mathrm{mhos} / \mathrm{cm} \times 100)$ & & $\%$ VSMOW & ${ }^{\circ} \mathrm{C}$ & $\%$ & $(\mu \mathrm{mhos} / \mathrm{cm} \times 100)$ & $\%$ VSMOW & ${ }^{\circ} \mathrm{C}$ \\
\hline 0 & 18.15 & 9.62 & 3.8 & 680 & 9.16 & -2.61 & 17 & 4.6 & 700 & -2.85 & 13.8 \\
\hline 1 & 18.2 & 9.52 & 3.8 & & & & 18.9 & 4.5 & 700 & -2.88 & 13.6 \\
\hline 1.5 & & & & & 9.09 & -2.68 & & & & & \\
\hline 2 & 17.1 & 8.57 & 4.3 & 650 & & & 16.1 & 4.2 & 620 & -2.9 & 13.5 \\
\hline 3 & 17.1 & 7.81 & 4.8 & 700 & 9.08 & -2.62 & 15.3 & 4.3 & 620 & -2.9 & 13.4 \\
\hline 4 & 17.1 & 6.52 & 4.8 & 700 & & & 15.1 & 4.4 & 620 & -2.88 & 13.4 \\
\hline 5 & 17.1 & 5.9 & 4.8 & 720 & 9.02 & -2.59 & 15.1 & 4.4 & 620 & -2.91 & 13.3 \\
\hline 6 & 16.275 & 4.09 & 5 & 720 & 8.72 & -2.8 & 15 & 4.4 & 620 & -2.88 & 13.3 \\
\hline 7 & 12.7 & 0.07 & 5.5 & 750 & 8.46 & -3.1 & 14 & 4.7 & 650 & -2.97 & 13.3 \\
\hline 8 & 11.15 & 0.07 & 5.2 & 700 & 8.07 & -3.11 & 11.9 & 4.8 & 600 & -3.05 & 13.2 \\
\hline 9 & 10.95 & 0.06 & 5.1 & 700 & & & 10.2 & 4.9 & 600 & -3.14 & 13.1 \\
\hline 10 & 10.25 & 0.05 & 5.3 & 690 & 7.91 & -3.19 & 10 & 4.9 & 600 & -3.19 & 13.1 \\
\hline 11 & 10.15 & 0.04 & 5.3 & 690 & & & 9.9 & 4.9 & 600 & -3.16 & 13.1 \\
\hline 12 & 10.05 & 0.04 & 5.3 & 690 & 7.8 & -3.22 & 9.6 & 4.9 & 590 & -3.19 & 12.6 \\
\hline 13 & 10 & 0.04 & 5.2 & 690 & & & 9.2 & 4.8 & 590 & -3.18 & 11.7 \\
\hline 14 & 9.95 & 0.04 & 5.2 & 690 & 7.79 & -3.28 & 9.1 & 4.9 & 590 & -3.17 & 11.4 \\
\hline 15 & 9.95 & 0.04 & 5.2 & 690 & & & 9 & 5 & 600 & -3.17 & 11.1 \\
\hline 16 & 9.9 & 0.04 & 5.2 & 690 & 7.74 & -3.2 & 9 & 5 & 600 & -3.18 & 11 \\
\hline 17 & 9.9 & 0.04 & 5.2 & 690 & & & 9 & 5 & 600 & -3.17 & 11 \\
\hline 18 & 9.85 & 0.04 & 5.2 & 690 & 7.68 & -3.41 & 9 & 5 & 600 & -3.18 & 10.9 \\
\hline 19 & 9.85 & 0.04 & 5.2 & 690 & & & 9 & 5 & 600 & -3.1 & 10.8 \\
\hline 20 & 9.85 & 0.04 & 5.2 & 690 & 7.64 & -3.38 & 9 & 5 & 600 & -3.19 & \\
\hline 21 & 9.75 & 0.04 & 5.2 & 690 & & & 9 & 5 & 610 & -3.26 & \\
\hline 22 & 9.7 & 0.04 & 5.2 & 690 & 7.62 & -3.3 & 9 & 4.9 & 590 & -3.22 & \\
\hline 23 & 9.4 & 0.03 & 5 & 650 & & & 8.6 & 4.9 & 590 & & \\
\hline 23.5 & & & 5 & 630 & & & & & & & \\
\hline
\end{tabular}

Table S1. Physical properties and oxygen-isotope composition of a water-depth profile from An Loch Mór, Ireland. 


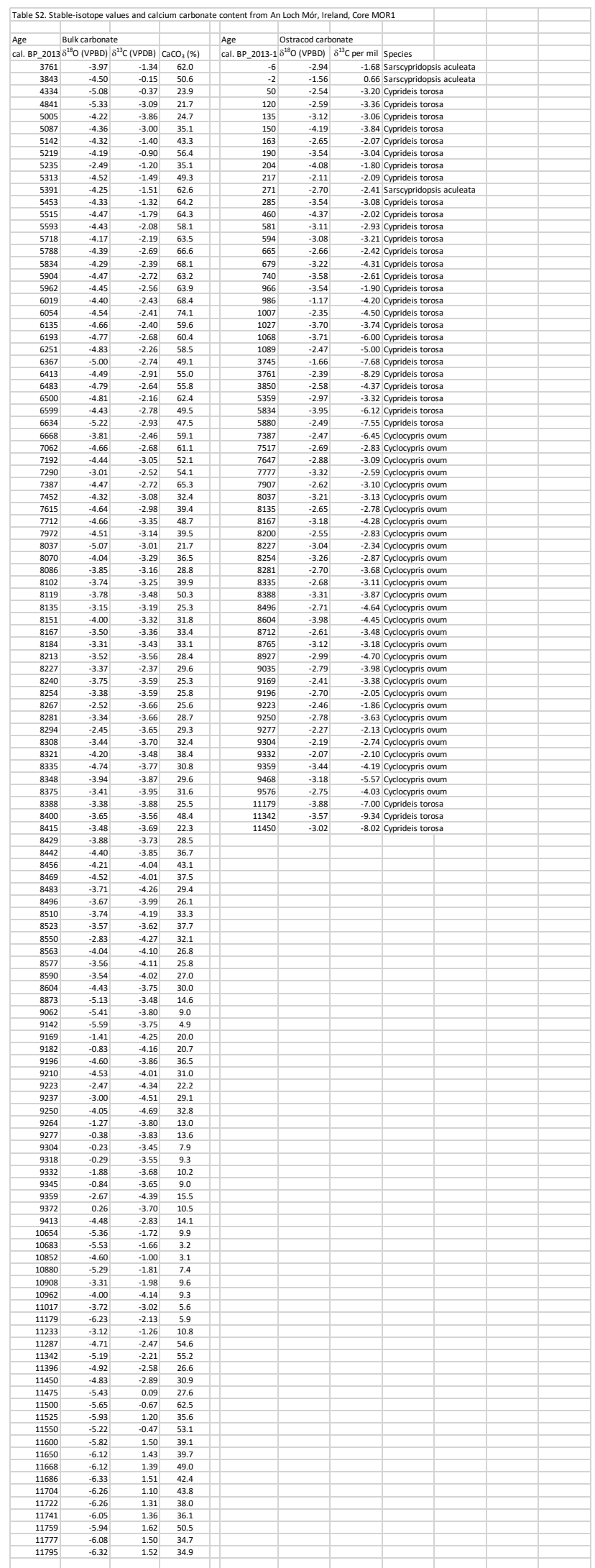

Table S2. Stable-isotope values and calcium carbonate content from An Loch Mór, Ireland, Core MOR1. 